\title{
TWO GROUPS OF PINUS CEMBRA FOREST COMMUNITIES IN THE TATRAS
}

\author{
P. KuČERA \\ Botanical Garden, Comenius University, Bratislava, Slovakia; E-mail: peter.kucera@uniba.sk
}

(Received 13 March, 2017; Accepted 21 June, 2017)

\begin{abstract}
A syntaxonomical statistical analysis of 110 phytocoenological relevés of the Western Carpathians Norway spruce-Arolla pine and Arolla pine phytocoenoses was performed. Resulting six relevé aggregates were evaluated at the rank of association. Two major groups of Arolla pine woodlands were distinguished following strong floristical differences and classified at the rank of alliances: non-carbonate group - Homogyno alpinae-Pinion cembrae (associations: Homogyno alpinae-Pinetum cembrae, Mylio taylorii-Pinetum cembrae, Prenantho purpureaePinetum cembrae, Cembro-Piceetum) and carbonate group - Calamagrostio variae-Pinion cembrae (associations: Seslerio tatrae-Pinetum cembrae, Cystopterido montanae-Pinetum cembrae).
\end{abstract}

Key words: Cembro-Piceetum, nomenclature, Piceetea excelsae, Pinus cembra woodland, syntaxonomy, Western Carpathians

\section{INTRODUCTION}

Arolla pine (Pinus cembra) is an autochthonous species of the Western Carpathians, growing in this region demonstrably in the Late Glacial (Jankovská 1984, 1988). [Statement that the last glacial period refugium of P. cembra was placed in the south of the Alps (Valachovič 2014) is inadequate.] At present, Arolla pine's natural distribution range in the Western Carpathians is limited to the mountain range of the Tatras on both sides of the Slovak/Polish state border.

Summary of $P$. cembra distribution in Polish Tatras was compiled by Myczkowski (1969). The most comprehensive survey of the Arolla pine's detailed occurrence in Slovakia was published by Jamnický (1981), who also describes localities of artificial plantations of $P$. cembra outside of its natural distribution 
where they are mostly of the Alpian provenience. Of identical allochthonous origin are also some P. cembra populations in the Tatras, where Siberian Pinus sibirica Du Tour was introduced as well (Jamnický 1981).

In the Tatras, Arolla pine is distributed mostly on the uppermost part of the forest belt, forming separate forest communities with a distinct physiognomy. The first phytocoenological relevé of $P$. cembra woodlands was published by Pawłowski et al. (1928) from Polish part of the Tatras. Later the works of Dostál (1932), Krajina (1933), Samek et al. (1957) and others in the Slovakian part followed (see overview by Kučera 2012). Myczkowski and Lesiński (1974) were the first who distinguished Tatras' Arolla pine communities as a separate unit in the rank of the association (Cembro-Piceetum).

The first synthesis of Norway spruce-Arolla pine and Arolla pine (onward simplified as "Arolla pine") plant communities in Slovakia was elaborated by Barančok (2002), who differentiated two subassociations within the association Cembro-Piceetum Myczkowski et Lesiński 1974 (i.e. C.-P. typicum, nom. inval., C.-P. calamagrostietosum variae, nom. inval.). Later, Kanka (2008a; see comparison by Kanka 2008b) described another separate Arolla pine community as the subassociation Vaccinio myrtilli-Piceetum pinetosum cembrae Kanka 2008, nom. inval.

Kučera (2012) published a comprehensive study of the Western Carpathian Norway spruce communities where $P$. cembra woodlands were split into three units: Cembro-Piceetum Myczkowski et Lesiński 1974, Sesleria tatrae-Pinus cembra community and Cystopteris montana-Pinus cembra-Picea abies community.

The view of Polish geobotanists on the Arolla pine woodlands of the Tatras is completely different, as they do not regard these as a separate unit (J. Matuszkiewicz 1977, 2002; W. Matuszkiewicz 1982, 2014); however, any phytocoenological study from Slovakia was considered.

The aim of this study is to bring insights into the phytosociological variability of the Tatras' Arolla pine woodlands and present a syntaxonomical evaluation of published relevés as well.

\section{MATERIAL AND METHODS}

By criterion of Pinus cembra presence, the preliminary set of 143 phytocoenological relevés was selected using the program Turboveg for Windows (Hennekens 2016) [cf. Hennekens and Schaminée 2001] from the Centrálna databáza... (2016) dataset provided for the prepared monograph Plant communities of Slovakia. Forest and shrub vegetation (Valachovič et al., in prep.) along with Pinus cembra relevés from Poland available to me (Pawłowski et al. 1928, Myczkowki and Lesiński 1974).

Subsequently, the following 33 relevés were removed: plantations outside of the $P$. cembra natural distribution range, relevés of shrub communities 
(with $P$. mugo), relevés with $P$. cembra appearance in the vegetation layers ${ }^{*} \mathrm{E}_{2}$ and $\mathrm{E}_{1}$ only [data with P. cembra cover-abundance " $\mathrm{r}$ " and higher in the layer $\mathrm{E}_{3}$ were retained (cf. explanation by Kučera 2012, p. 199)], stands of young successional stages, relevés without recorded bryophytes [retained were problematic relevés of Myczkowski and Lesiński (1974): only Rhytidiadelphus loreus is recorded in the published table], methodologically incompatible or other unclear relevés, relevés without data on plot size or with plot size smaller than $100 \mathrm{~m}^{2}(10 \times 10 \mathrm{~m})$ as well as relevés of plot size exceeding the area $40 \times$ $40 \mathrm{~m}^{2}$. This decision was made with respect to a considerably small number of relevés of some special types of Arolla pine communities (e.g., Myczkowski and Lesiński 1974, Barančok and Varšavová 1995).

A final dataset of 110 relevés was exported for further modifications and preliminary analyses in the JUICE program (Tichý 2016) [cf. Tichý 2002].

For purposes of the statistical analysis of fidelity, the following steps were applied:

Species data of the final dataset were edited in JUICE: data of unequal taxonomic rank (Luzula luzuloides and L. luzuloides ssp. luzuloides; Senecio nemorensis agg., S. ovatus, S. fuchsii; etc.) as well as all records of Sphagnum (incl. Sphagnum sp.), $\mathrm{E}_{2}+\mathrm{E}_{1}$ records of shrub species (Pinus mugo [also $\mathrm{E}_{3}$ in 1 rel.], Ribes petraeum, Lonicera nigra, Juniperus sibirica) and of Salix silesiaca were merged.

The following were deleted: juveniles (Sorbus aucuparia, 1 rel.), layers $\mathrm{E}_{2}+\mathrm{E}_{1}$ records of tree species not contributing to phytosociological variability of the plant communities under consideration (Picea abies, Pinus cembra, Sorbus aucuparia) as well as layers $\mathrm{E}_{2}+\mathrm{E}_{1}$ records of Betula pubescens and Abies alba; sporadic data on Larix decidua were merged into one layer. With respect to habitat type, record of Calamagrostis sp. (1 rel., Pawłowski et al. 1928) was subjectively merged with that of $C$. villosa.

Edited JUICE-dataset was processed in software package SYN-TAX 2000 (Podani 2001a) using the coefficient for ordinal phytosociological data - Podani's discordance (see more Podani 2001b). According to the author's manual (Podani 2001b, p. 43), hierarchical clustering (dendrogram) was performed, and, subsequently, non-hierarchical clustering with partition from the dendrogram using various number of clusters (2-6) was performed to see the variation pattern of relevé grouping. The final classification of non-carbonate phytocoenoses (100 out of total 110 relevés) is derived from 4 clusters of nonhierarchical clustering with several adjustments from the initial dendrogram (Fig. 1).

The differential attributes of the respective plant community (fidelity and frequency values) and resulting Table 1 were elaborated from the semi-

* $\quad \mathrm{E}_{3}$ - canopy (trees), $\mathrm{E}_{2}$ - understorey (shrubs), $\mathrm{E}_{1}$ - field layer (herbs, grasses, etc.), $\mathrm{E}_{0}$ ground layer (bryophytes, lichens) (Klika 1948, p. 29-30; Rodwell et al. 1991). 
modified final dataset (see above: without deletion and merging of selected taxa) within JUICE (Tichý 2016); the concept of fidelity was used (Chytrý et al. 2002; phi coefficient $-\phi)$. Fidelity calculation was based on the presence/ absence data with a standardization of relevé groups to an equal size (associations: $16.667 \%$, alliances: $50 \%$ of the total dataset). Performing the Fisher's exact test, zero fidelity was given to species with significance $P>0.05$ in a particular cluster (Tichý and Chytrý 2006).

Nomenclature of the vascular plants, bryophytes and lichens follows the lists of Marhold et al. (1998), Kubinská and Janovicová (1998) and Guttová et al. (2013), if otherwise then with an author citation. Syntaxa nomenclature rules are applied in accordance with Weber et al. (2000).

\section{RESULTS AND DISCUSSION}

Table 1 shows considerable differences in floristic composition between two basic groups of the Tatras' Arolla pine communities (A, B). Species richness of the $B$ group reflects the special habitat conditions originating from cal-

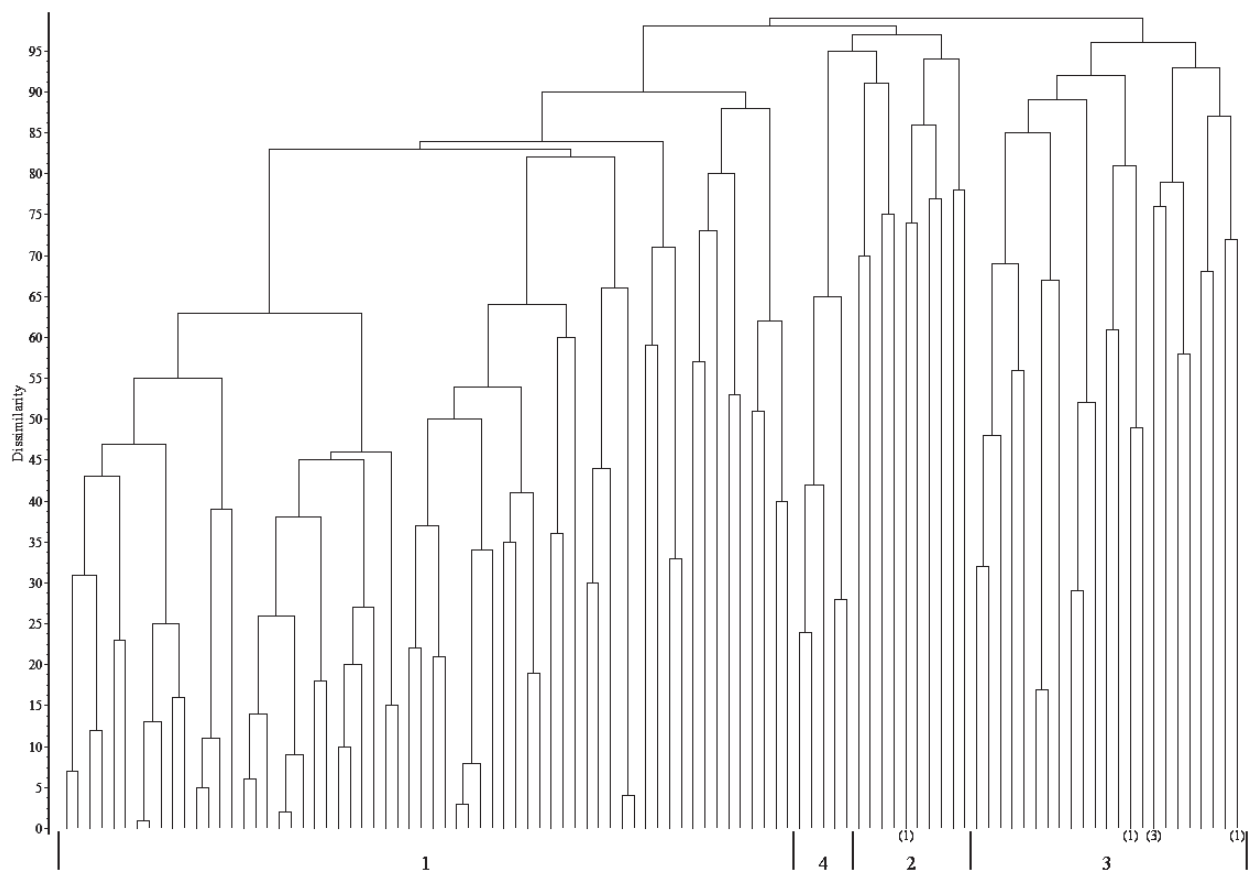

Fig. 1. The initial dendrogram of the non-carbonate phytocoenoses. Group numbers (1-4) are identical with the numbers of the respective final association (see Table 1). Numbers in brackets indicate changed relevé classification according to non-hierarchical clustering of the dataset 
cium rich geological bedrock: limestones and dolomites. This is the identical pattern which rules division of Western Carpathian supramontane Norway

\section{Table 1}

Differential table of Arolla pine communities of the Tatras with fidelity $(\phi \times 100)$ and constancy in exponent (A - Homogyno alpinae-Pinion cembrae, Column 1 - Homogyno alpinae-Pinetum cembrae, Column 2 - Prenantho purpureae-Pinetum cembrae, Column 3 - Mylio taylorii-Pinetum cembrae, Column 4 - Cembro-Piceetum; B - Calamagrostio variae-Pinion cembrae, Column 5 - Seslerio tatrae-Pinetum cembrae, Column 6 - Cystopterido montanae-Pinetum cembrae)

\begin{tabular}{|c|c|c|c|c|c|c|c|c|c|c|c|c|}
\hline & \multicolumn{8}{|c|}{ A } & \multicolumn{4}{|c|}{ B } \\
\hline Column & \multicolumn{2}{|c|}{1} & \multicolumn{2}{|c|}{2} & \multicolumn{2}{|c|}{3} & \multicolumn{2}{|c|}{4} & \multicolumn{2}{|c|}{5} & \multicolumn{2}{|c|}{6} \\
\hline Number of relevés & \multicolumn{2}{|c|}{65} & \multicolumn{2}{|c|}{10} & \multicolumn{2}{|c|}{20} & \multicolumn{2}{|c|}{5} & \multicolumn{2}{|c|}{5} & \multicolumn{2}{|c|}{5} \\
\hline \multicolumn{13}{|c|}{ Differential tree and shrub species } \\
\hline \multicolumn{13}{|l|}{$\mathbf{E}_{3}$} \\
\hline Abies alba & - & & - & & - & & 76 & 80 & - & & - & 20 \\
\hline Populus tremula & - & & - & . & - & & 41 & 20 & - & & - & \\
\hline Acer pseudoplatanus & - & & - & & - & & 41 & 20 & - & & - & \\
\hline Pinus sylvestris & - & & - & & - & & 41 & 20 & - & & - & \\
\hline Salix caprea & - & & - & & - & & - & & 59 & 40 & - & \\
\hline Betula carpatica & - & & - & & - & & 54 & 100 & 18 & 60 & 36 & 80 \\
\hline Sorbus aucuparia & - & 25 & - & 50 & 1 & 65 & 34 & 100 & 34 & 100 & - & 40 \\
\hline \multicolumn{13}{|l|}{$\mathbf{E}_{2}$} \\
\hline Populus tremula & - & & - & . & - & . & 41 & 20 & - & & - & \\
\hline Daphne mezereum & - & & - & & - & & - & & 41 & 20 & - & \\
\hline Salix caprea & - & & - & . & - & & - & & - & & 41 & 20 \\
\hline Abies alba & - & & - & . & - & & 35 & 40 & - & & 35 & 40 \\
\hline Lonicera nigra & - & & - & . & - & & 28 & 40 & 52 & 60 & - & \\
\hline Salix silesiaca & - & 2 & 6 & 40 & - & & 25 & 60 & 62 & 100 & - & \\
\hline Pinus mugo & - & 29 & - & 40 & 27 & 90 & 36 & 100 & 36 & 100 & - & \\
\hline \multicolumn{13}{|l|}{$\mathbf{E}_{1}$} \\
\hline Juniperus sibirica & - & 2 & 44 & 30 & - & 5 & - & & - & & - & \\
\hline Lonicera nigra & - & 9 & 36 & 60 & - & & - & & - & 40 & - & 40 \\
\hline Salix silesiaca & - & 2 & - & 10 & - & & - & & 93 & 100 & - & \\
\hline Daphne mezereum & - & & - & . & - & & - & & 89 & 100 & - & 20 \\
\hline Ribes petraeum & - & 3 & 8 & 30 & - & & - & & 83 & 100 & - & \\
\hline Abies alba & - & & - & & - & . & - & & - & & 59 & 40 \\
\hline Acer pseudoplatanus & - & & - & & - & & - & & - & & 59 & 40 \\
\hline
\end{tabular}


Table 1 (continued)

\begin{tabular}{|c|c|c|c|c|c|c|c|c|c|c|c|c|}
\hline \multirow[b]{2}{*}{ Column } & \multicolumn{8}{|c|}{ A } & \multicolumn{4}{|c|}{ B } \\
\hline & \multicolumn{2}{|c|}{1} & \multicolumn{2}{|c|}{2} & \multicolumn{2}{|c|}{3} & \multicolumn{2}{|c|}{4} & \multicolumn{2}{|c|}{5} & \multicolumn{2}{|c|}{6} \\
\hline \multicolumn{13}{|l|}{ Other tree and shrub species } \\
\hline \multicolumn{13}{|l|}{$\mathbf{E}_{3}$} \\
\hline Pinus cembra & - & 100 & - & 100 & - & 100 & - & 100 & - & 100 & - & 100 \\
\hline Picea abies & - & 98 & - & 100 & - & 100 & - & 100 & - & 80 & - & 100 \\
\hline Larix decidua & - & 9 & - & 30 & - & & - & 40 & - & & - & 40 \\
\hline Pinus mugo & - & 2 & - & . & - & & - & & - & . & - & . \\
\hline \multicolumn{13}{|l|}{$\mathbf{E}_{2}$} \\
\hline Betula carpatica & - & 2 & - & & - & & 62 & 100 & 43 & 80 & - & 20 \\
\hline Pinus cembra & - & 11 & - & 30 & 7 & 50 & - & 60 & 34 & 80 & - & 20 \\
\hline Sorbus aucuparia & - & 18 & - & 50 & 6 & 70 & - & 80 & 34 & 100 & - & 60 \\
\hline Picea abies & - & 38 & - & 70 & 23 & 100 & - & 100 & - & 100 & - & 60 \\
\hline Larix decidua & - & 2 & - & 10 & - & & - & 20 & - & & - & \\
\hline Ribes petraeum & - & & - & 10 & - & & - & & - & 20 & - & \\
\hline Juniperus sibirica & - & 2 & - & . & - & & - & & - & . & - & \\
\hline \multicolumn{13}{|l|}{$\mathbf{E}_{1}$} \\
\hline Picea abies & - & 48 & - & 50 & - & 60 & - & & - & 40 & 45 & 100 \\
\hline Betula carpatica & - & & - & & - & & 38 & 60 & - & 20 & 38 & 60 \\
\hline Sorbus aucuparia & - & 89 & - & 90 & - & 100 & - & 100 & - & 100 & - & 100 \\
\hline Pinus cembra & - & 28 & - & 40 & - & 50 & - & 60 & - & 60 & - & 80 \\
\hline Pinus mugo & - & 11 & - & 10 & - & 20 & - & & - & & - & \\
\hline Larix decidua & - & 2 & - & 10 & - & & - & & - & & - & \\
\hline Rosa pendulina & - & & - & 10 & - & & - & & - & 20 & - & \\
\hline Salix caprea & - & & - & 10 & - & & - & & - & & - & 20 \\
\hline \multicolumn{13}{|c|}{ Differential field layer species $\left(E_{1}\right)$} \\
\hline Avenella flexuosa & 28 & 97 & - & 90 & - & 95 & - & & - & 20 & - & 100 \\
\hline Cicerbita alpina & - & 3 & 51 & 50 & - & & - & & - & 20 & - & \\
\hline Gentiana asclepiadea & - & 26 & 50 & 70 & - & 20 & - & & - & & - & 20 \\
\hline Athyrium filix-femina & - & 9 & 46 & 50 & - & 5 & - & & - & & - & 20 \\
\hline Galeobdolon montanum & - & & 41 & 20 & - & & - & & - & & - & \\
\hline Aconitum firmum ssp. firmum & - & & 41 & 20 & - & & - & & - & & - & \\
\hline Phegopteris connectilis & - & 2 & 38 & 40 & - & 10 & - & & - & & - & 20 \\
\hline
\end{tabular}


Table 1 (continued)

\begin{tabular}{|c|c|c|c|c|c|c|c|c|c|c|c|c|}
\hline \multirow{3}{*}{$\begin{array}{l}\text { Column } \\
\text { Ranunculus platanifolius }\end{array}$} & \multicolumn{8}{|c|}{ A } & \multicolumn{4}{|c|}{$\mathrm{B}$} \\
\hline & \multicolumn{2}{|c|}{1} & \multicolumn{2}{|c|}{2} & \multicolumn{2}{|c|}{3} & \multicolumn{2}{|c|}{4} & \multicolumn{2}{|c|}{5} & \multicolumn{2}{|c|}{6} \\
\hline & - & 2 & 34 & 30 & - & . & - & . & - & 20 & - & . \\
\hline Doronicum austriacum & - & 3 & 33 & 30 & - & & - & & - & 20 & - & . \\
\hline Veratrum album ssp. lobelianum & - & 6 & 32 & 60 & - & 20 & - & & - & 40 & - & 40 \\
\hline Adenostyles alliariae & - & 42 & 25 & 70 & - & & - & & - & 80 & - & 60 \\
\hline Lycopodium annotinum & - & 17 & - & 40 & 37 & 80 & - & 60 & - & & - & 40 \\
\hline Empetrum nigrum agg. & - & & - & & - & 10 & 81 & 80 & - & & - & \\
\hline Listera cordata & - & 2 & - & & - & & 75 & 80 & - & & - & 20 \\
\hline Vaccinium gaultherioides & - & 2 & - & & - & & 73 & 60 & - & & - & \\
\hline Athyrium distentifolium & - & 6 & - & 10 & - & & 53 & 60 & - & & - & 20 \\
\hline Clematis alpina & - & & - & & - & & - & & 89 & 100 & - & 20 \\
\hline Pyrola rotundifolia & - & & - & . & - & & - & & 87 & 80 & - & \\
\hline Hedysarum hedysaroides & - & & - & & - & & - & & 87 & 80 & - & \\
\hline Cortusa matthioli & - & & - & . & - & & - & & 87 & 80 & - & \\
\hline Bartsia alpina & - & & - & . & - & & - & & 87 & 80 & - & \\
\hline Cystopteris fragilis & - & & - & . & - & & - & & 81 & 100 & 17 & 40 \\
\hline Sesleria tatrae & - & & - & . & - & & - & & 81 & 100 & 17 & 40 \\
\hline Swertia perennis & - & & - & & - & & - & & 76 & 80 & - & 20 \\
\hline Festuca versicolor & - & & - & & - & & - & & 74 & 60 & - & \\
\hline Moehringia muscosa & - & & - & & - & & - & & 74 & 60 & - & \\
\hline Salix reticulata & - & & - & & - & & - & & 74 & 60 & - & \\
\hline Salix retusa & - & & - & & - & & - & & 74 & 60 & - & \\
\hline Androsace chamaejasme & - & & - & . & - & & - & & 74 & 60 & - & \\
\hline Poa alpina & - & & - & & - & & - & & 74 & 60 & - & . \\
\hline Aster bellidiastrum & - & & - & . & - & & - & & 74 & 60 & - & . \\
\hline Rhodiola rosea & - & & - & . & - & & - & & 74 & 60 & - & \\
\hline Cirsium erisithales & - & & - & & - & & - & & 74 & 60 & - & \\
\hline Carex sempervirens ssp. laxiflora & - & & - & . & - & & - & & 74 & 60 & - & \\
\hline Ranunculus alpestris & - & & - & & - & & - & & 74 & 60 & - & \\
\hline Campanula tatrae ssp. tatrae & - & 3 & - & 20 & - & & - & & 73 & 100 & - & 40 \\
\hline Phyteuma spicatum & - & & - & 10 & - & & - & & 71 & 80 & - & 20 \\
\hline Rumex alpestris & - & 9 & - & & - & & - & & 67 & 60 & - & \\
\hline
\end{tabular}


Table 1 (continued)

\begin{tabular}{|c|c|c|c|c|c|c|c|c|c|c|c|}
\hline \multirow[b]{2}{*}{ Column } & \multicolumn{7}{|c|}{ A } & \multicolumn{4}{|c|}{ B } \\
\hline & 1 & & 2 & & 3 & & 4 & 5 & & 6 & \\
\hline Leucanthemum rotundifolium & - & & - & 10 & - & & - & 67 & 60 & - & . \\
\hline Geranium sylvaticum & - & & - & 10 & - & & - & 67 & 60 & - & \\
\hline Asplenium viride & - & & - & & - & & - & 67 & 80 & 22 & 40 \\
\hline Myosotis alpestris & - & & - & & - & & - & 59 & 40 & - & \\
\hline Saxifraga wahlenbergii & - & & - & & - & & - & 59 & 40 & - & \\
\hline Bistorta major & - & & - & & - & & - & 59 & 40 & - & \\
\hline Helianthemum grandiflorum & - & & - & & - & & - & 59 & 40 & - & \\
\hline Bistorta vivipara & - & & - & & - & & - & 59 & 40 & - & \\
\hline Astragalus norvegicus & - & 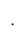 & - & & - & & - & 59 & 40 & - & \\
\hline Alchemilla sp. & - & & - & & - & & - & 59 & 40 & - & \\
\hline Phyteuma orbiculare & - & & - & & - & & - & 59 & 40 & - & \\
\hline Carex firma & - & & - & & - & & - & 59 & 40 & - & \\
\hline Erysimum witmannii & - & & - & & - & & - & 59 & 40 & - & \\
\hline Cerastium arvense ssp. glandulosum & - & & - & & - & & - & 59 & 40 & - & \\
\hline Saxifraga paniculata & - & & - & & - & & - & 59 & 40 & - & \\
\hline Dryas octopetala & - & & - & & - & & - & 59 & 40 & - & \\
\hline Pedicularis verticillata & - & & - & & - & & - & 59 & 40 & - & \\
\hline Selaginella selaginoides & - & & - & 10 & - & & - & 51 & 40 & - & \\
\hline Crepis jacquinii ssp. jacquinii & - & & - & & - & & - & 44 & 40 & - & 20 \\
\hline Gymnocarpium dryopteris & - & 5 & 24 & 60 & - & & - & 43 & 80 & 24 & 60 \\
\hline Cyanus mollis & - & & - & & - & & - & 41 & 20 & - & \\
\hline Astrantia major & - & & - & & - & & - & 41 & 20 & - & \\
\hline Parnassia palustris & - & & - & & - & & - & 41 & 20 & - & . \\
\hline Ranunculus thora & - & & - & & - & & - & 41 & 20 & - & . \\
\hline Viola biflora & - & & - & & - & & - & 41 & 20 & - & . \\
\hline Thalictrum aquilegiifolium & - & & - & & - & & - & 41 & 20 & - & \\
\hline Poa chaixii & - & & - & & - & & - & 41 & 20 & - & . \\
\hline Geum rivale & - & & - & & - & & - & 41 & 20 & - & \\
\hline Tofieldia calyculata & - & & - & & - & & - & 41 & 20 & - & \\
\hline Scabiosa lucida & - & & - & & - & & - & 41 & 20 & - & \\
\hline Pinguicula alpina & - & & - & & - & & - & 41 & 20 & - & \\
\hline
\end{tabular}


Table 1 (continued)

\begin{tabular}{|c|c|c|c|c|c|c|c|c|c|c|c|c|}
\hline \multirow[b]{2}{*}{ Column } & \multicolumn{8}{|c|}{ A } & \multicolumn{4}{|c|}{ B } \\
\hline & \multicolumn{2}{|c|}{1} & \multicolumn{2}{|c|}{2} & \multicolumn{2}{|c|}{3} & \multicolumn{2}{|c|}{4} & \multicolumn{2}{|c|}{5} & \multicolumn{2}{|l|}{6} \\
\hline Saxifraga aizoides & - & & - & & - & & - & & 41 & 20 & - & \\
\hline Pleurospermum austriacum & - & & - & & - & & - & & 41 & 20 & - & \\
\hline Melampyrum sylvaticum & - & 2 & - & 10 & - & 5 & - & 20 & 39 & 60 & - & 40 \\
\hline Luzula sylvatica & - & 55 & - & 60 & - & 40 & - & 20 & 37 & 100 & - & 80 \\
\hline Moneses uniflora & - & 2 & - & 10 & - & & - & 40 & 35 & 60 & - & 40 \\
\hline Huperzia selago & - & 3 & - & 50 & 24 & 75 & - & 40 & 28 & 80 & - & 40 \\
\hline Dactylorhiza majalis & - & & - & . & - & & - & & - & & 59 & 40 \\
\hline Crepis paludosa & - & & - & . & - & & - & & - & & 59 & 40 \\
\hline Maianthemum bifolium & - & 2 & - & . & - & . & - & & - & & 58 & 40 \\
\hline Galium schultesii & - & & - & 10 & - & & - & & - & 20 & 56 & 60 \\
\hline Mycelis muralis & - & & - & 10 & - & & - & & - & & 51 & 40 \\
\hline Heracleum sphondylium & - & & - & & - & & - & & - & & 41 & 20 \\
\hline $\begin{array}{l}\text { Asplenium trichomanes ssp. quad- } \\
\text { rivalens }\end{array}$ & - & & - & & - & & - & & - & & 41 & 20 \\
\hline Cardaminopsis halleri & - & & - & . & - & & - & & - & & 41 & 20 \\
\hline Listera ovata & - & & - & & - & & - & & - & & 41 & 20 \\
\hline Epilobium montanum & - & & - & & - & & - & & - & & 41 & 20 \\
\hline Campanula serrata & - & & - & & - & & - & & - & & 41 & 20 \\
\hline Dentaria glandulosa & - & & - & & - & & - & & - & & 41 & 20 \\
\hline \multicolumn{13}{|c|}{ Differential field layer species for two associations $\left(E_{1}\right)$} \\
\hline Prenanthes purpurea & - & 23 & 42 & 80 & - & 5 & - & & - & 20 & 42 & 80 \\
\hline Calamagrostis arundinacea & - & 22 & 25 & 50 & - & & - & & - & & 56 & 80 \\
\hline Polystichum lonchitis & - & & - & & - & & 35 & 40 & 35 & 40 & - & \\
\hline Calamagrostis varia & - & & - & & - & & - & & 74 & 100 & 33 & 60 \\
\hline Valeriana tripteris & - & & - & 10 & - & & - & & 65 & 100 & 46 & 80 \\
\hline Soldanella hungarica & - & 5 & - & 30 & - & & - & & 50 & 80 & 30 & 60 \\
\hline Hieracium murorum & - & 8 & - & 30 & - & & - & & 49 & 80 & 29 & 60 \\
\hline Cystopteris montana & - & & - & . & - & & - & & 38 & 60 & 59 & 80 \\
\hline Polygonatum verticillatum & - & 3 & - & 20 & - & & - & & 37 & 60 & 37 & 60 \\
\hline
\end{tabular}

Other field layer species with higher constancy $\left(E_{1}\right)$

Vaccinium myrtillus

\begin{tabular}{llllllll|llll}
- & 100 & - & 100 & - & 100 & - & 100 & - & 60 & - & 100 \\
16 & 89 & - & 90 & - & 75 & - & 60 & - & 80 & - & 40 \\
\hline
\end{tabular}


Table 1 (continued)

\begin{tabular}{|c|c|c|c|c|c|c|c|c|c|c|c|c|}
\hline \multirow{3}{*}{$\begin{array}{l}\text { Column } \\
\text { Homogyne alpina }\end{array}$} & \multicolumn{8}{|c|}{ A } & \multicolumn{4}{|c|}{ B } \\
\hline & \multicolumn{2}{|c|}{1} & \multicolumn{2}{|c|}{2} & \multicolumn{2}{|c|}{3} & \multicolumn{2}{|c|}{4} & \multicolumn{2}{|c|}{5} & \multicolumn{2}{|c|}{6} \\
\hline & - & 83 & - & 80 & - & 75 & - & 80 & - & 60 & - & 80 \\
\hline Oxalis acetosella & - & 82 & - & 100 & - & 70 & - & & - & 60 & - & 80 \\
\hline Vaccinium vitis-idaea & - & 65 & - & 70 & 9 & 95 & - & 100 & - & 100 & - & 100 \\
\hline Calamagrostis villosa & - & 62 & - & 80 & - & 50 & - & 100 & - & & - & \\
\hline Rubus idaeus & 20 & 62 & - & 50 & - & 25 & - & 20 & - & 20 & - & 60 \\
\hline Luzula luzuloides & 15 & 55 & - & 60 & - & 15 & - & & - & 20 & - & 80 \\
\hline Senecio nemorensis agg. & - & 28 & - & 30 & - & & - & & - & 40 & - & 20 \\
\hline Solidago virgaurea & - & 22 & - & 40 & - & 5 & - & & - & & - & \\
\hline Gentiana punctata & - & 3 & - & 30 & 15 & 25 & - & 20 & - & & - & \\
\hline Dryopteris carthusiana & - & 11 & - & 10 & - & & - & & - & & - & \\
\hline Epilobium angustifolium & - & 6 & - & 10 & - & & - & & - & & - & \\
\hline Dryopteris filix-mas & - & & - & 10 & - & 10 & - & & - & & - & 20 \\
\hline Corallorrhiza trifida & - & 2 & - & & - & & - & 20 & - & 20 & - & \\
\hline Ligusticum mutellina & - & 2 & - & 10 & - & & - & & - & 20 & - & \\
\hline Hylotelephium argutum & - & 2 & - & 10 & - & & - & & - & & - & \\
\hline Stellaria nemorum & - & 2 & - & 10 & - & & - & & - & & - & \\
\hline Streptopus amplexifolius & - & & - & 10 & - & & - & & - & & - & \\
\hline Paris quadrifolia & - & & - & 10 & - & & - & & - & & - & \\
\hline Ranunculus platanifolius & - & & - & 10 & - & & - & & - & & - & \\
\hline Soldanella carpatica & - & & - & 10 & - & & - & & - & & - & \\
\hline Lilium martagon & - & & - & 10 & - & & - & & - & & - & \\
\hline Hieracium lachenalii & - & & - & 10 & - & & - & & - & & - & \\
\hline Potentilla aurea & - & & - & 10 & - & & - & & - & & - & \\
\hline Hieracium bifidum & - & & - & 10 & - & & - & & - & & - & \\
\hline Jovibarba globifera ssp. glabrescens & - & & - & 10 & - & & - & & - & & - & \\
\hline Crepis conyzifolia & - & & - & 10 & - & & - & & - & & - & \\
\hline Calluna vulgaris & - & & - & 10 & - & & - & & - & & - & \\
\hline Chaerophyllum hirsutum & - & & - & 10 & - & & - & & - & & - & \\
\hline Myosotis scorpioides & - & & - & 10 & - & & - & & - & & - & \\
\hline Oreochloa disticha & - & & - & 10 & - & & - & & - & & - & \\
\hline Polypodium vulgare & - & & - & 10 & - & & - & & - & & - & \\
\hline
\end{tabular}


Table 1 (continued)

\begin{tabular}{|c|c|c|c|c|c|c|c|c|c|c|c|c|}
\hline \multirow[b]{2}{*}{ Column } & \multicolumn{8}{|c|}{ A } & \multicolumn{4}{|c|}{$\mathrm{B}$} \\
\hline & \multicolumn{2}{|c|}{1} & \multicolumn{2}{|c|}{2} & \multicolumn{2}{|c|}{3} & \multicolumn{2}{|c|}{4} & \multicolumn{2}{|c|}{5} & \multicolumn{2}{|c|}{6} \\
\hline \multicolumn{13}{|c|}{ Differential ground layer species $\left(\mathrm{E}_{0}\right)$} \\
\hline Plagiomnium affine & 28 & 9 & - & & - & & - & & - & & - & \\
\hline Brachythecium velutinum & - & & 41 & 20 & - & & - & & - & & - & \\
\hline Cladonia squamosa var. subsquamosa & - & 3 & 37 & 20 & - & & - & & - & & - & \\
\hline Rhytidiadelphus triquetrus & - & 11 & 29 & 50 & - & 15 & - & & - & 40 & - & 20 \\
\hline Lophozia ventricosa & - & 5 & - & 40 & 75 & 95 & - & & - & & - & \\
\hline Sphagnum girgensohnii & - & 15 & - & 30 & 75 & 95 & - & & - & & - & \\
\hline Mylia taylorii & - & & - & 30 & 67 & 95 & - & & - & & - & 40 \\
\hline Dicranoweisia crispula & - & & - & 10 & 67 & 60 & - & & - & & - & \\
\hline Dicranella heteromalla & - & & - & 30 & 64 & 70 & - & & - & & - & \\
\hline Cladonia coccifera & - & & - & 10 & 63 & 55 & - & & - & & - & \\
\hline Cladonia chlorophaea & - & & - & 30 & 60 & 65 & - & & - & & - & \\
\hline Barbilophozia attenuata & - & 2 & - & 20 & 56 & 55 & - & & - & & - & \\
\hline Calypogeia integristipula & - & 32 & - & 30 & 55 & 75 & - & & - & & - & \\
\hline Cetraria islandica & - & 2 & - & 20 & 55 & 65 & - & & - & & - & 20 \\
\hline Ditrichum heteromallum & - & & - & 20 & 53 & 50 & - & & - & & - & \\
\hline Racomitrium microcarpon & - & & - & 20 & 53 & 50 & - & & - & & - & \\
\hline Lophozia sudetica & - & 2 & - & 10 & 50 & 40 & - & & - & & - & \\
\hline Racomitrium lanuginosum & - & & - & & 46 & 25 & - & & - & & - & \\
\hline Cladonia gracilis & - & & - & 20 & 44 & 40 & - & & - & & - & \\
\hline Barbilophozia lycopodioides & - & 2 & - & 20 & 43 & 40 & - & & - & & - & \\
\hline Diplophyllum taxifolium & - & 2 & - & 20 & 43 & 40 & - & & - & & - & \\
\hline Polytrichum formosum & - & 54 & - & 90 & 36 & 100 & - & & - & 60 & - & 60 \\
\hline Pohlia elongata & - & & - & & 35 & 15 & - & & - & & - & \\
\hline Cladonia rangiferina & - & & - & 20 & 35 & 30 & - & & - & & - & \\
\hline Calypogeia azurea & - & 2 & - & 20 & 34 & 30 & - & & - & & - & \\
\hline Plagiothecium curvifolium & - & 46 & - & 50 & 33 & 70 & - & & - & 40 & - & \\
\hline $\begin{array}{l}\text { Chiloscyphus polyanthos var. pal- } \\
\text { lescens }\end{array}$ & - & 2 & - & & 33 & 15 & - & & - & & - & \\
\hline Cladonia pyxidata & - & & - & & 29 & 10 & - & & - & & - & \\
\hline Barbilophozia floerkei & - & & - & & 29 & 10 & - & & - & & - & \\
\hline Dicranum scoparium & - & 91 & - & 90 & 26 & 100 & - & & - & 100 & - & 60 \\
\hline
\end{tabular}


Table 1 (continued)

\begin{tabular}{|c|c|c|c|c|c|c|c|c|c|c|c|c|}
\hline \multirow{3}{*}{$\begin{array}{l}\text { Column } \\
\text { Bazzania trilobata }\end{array}$} & \multicolumn{8}{|c|}{ A } & \multicolumn{4}{|c|}{ B } \\
\hline & \multicolumn{2}{|c|}{1} & \multicolumn{2}{|c|}{2} & \multicolumn{2}{|c|}{3} & \multicolumn{2}{|c|}{4} & \multicolumn{2}{|c|}{5} & \multicolumn{2}{|c|}{6} \\
\hline & - & & - & 10 & 26 & 35 & - & & - & 40 & - & \\
\hline Cladonia digitata & - & 8 & - & 20 & 25 & 25 & - & & - & & - & \\
\hline Rhytidiadelphus loreus & - & 2 & - & . & - & & 58 & 40 & - & & - & \\
\hline Sphagnum capillifolium & - & 5 & - & & - & & - & & 55 & 40 & - & \\
\hline Marchantia polymorpha & - & . & - & . & - & & - & & 41 & 20 & - & \\
\hline Rhizomnium punctatum & - & 2 & - & 10 & - & 5 & - & & 36 & 40 & - & 20 \\
\hline Leucobryum glaucum & - & & - & . & - & & - & & - & & 41 & 20 \\
\hline \multicolumn{13}{|c|}{ Differential ground layer species for two associations $\left(E_{0}\right)$} \\
\hline Blepharostoma trichophyllum & - & 5 & 42 & 50 & 29 & 40 & - & & - & & - & · \\
\hline Bazzania tricrenata & - & 3 & 29 & 50 & 62 & 80 & - & & - & & - & \\
\hline Pleurozium schreberi & - & 23 & - & 40 & 28 & 65 & - & & 42 & 80 & - & \\
\hline Mnium spinosum & - & & - & 10 & - & & - & & 31 & 40 & 31 & 40 \\
\hline \multicolumn{13}{|c|}{ Other ground layer species with higher constancy $\left(\mathrm{E}_{0}\right)$} \\
\hline Hylocomium splendens & - & 28 & 20 & 80 & 16 & 75 & - & & - & 80 & - & 80 \\
\hline Plagiothecium undulatum & - & 5 & - & 30 & 18 & 45 & - & & - & 40 & - & 40 \\
\hline Tetraphis pellucida & - & 8 & - & 10 & 24 & 35 & - & & - & 20 & - & 20 \\
\hline Lepidozia reptans & - & 9 & - & 10 & - & 25 & - & & - & & - & 20 \\
\hline Hypnum cupressiforme & - & 5 & - & 30 & - & 20 & - & & - & 20 & - & . \\
\hline Ptilidium ciliare & - & & - & 20 & 18 & 30 & - & & - & 20 & - & 20 \\
\hline Dicranum montanum & - & 9 & - & 10 & - & & - & & - & & - & 40 \\
\hline Polytrichum juniperinum & - & 3 & - & 20 & - & 5 & - & & - & & - & \\
\hline Anastrepta orcadensis & - & 2 & - & 10 & 23 & 15 & - & & - & & - & \\
\hline Ptilidium pulcherrimum & - & 2 & - & 10 & - & 10 & - & & - & & - & \\
\hline Ptilium crista-castrensis & - & 3 & - & 10 & - & & - & & - & & - & \\
\hline Calypogeia neesiana & - & 3 & - & 10 & - & & - & & - & & - & \\
\hline Polytrichum commune & - & 3 & - & 10 & - & & - & & - & & - & \\
\hline Sphagnum quinquefarium & - & 3 & - & & - & & - & & - & & - & 20 \\
\hline Entodon schleicheri & - & 2 & - & 10 & - & & - & & - & & - & \\
\hline Hylocomium umbratum & - & 2 & - & 10 & - & & - & & - & & - & \\
\hline Polytrichum longisetum & - & 2 & - & 10 & - & & - & & - & & - & \\
\hline Eurhynchium angustirete & - & . & - & & - & & - & & - & 20 & - & 20 \\
\hline Plagiothecium denticulatum & - & . & - & 10 & - & . & - & . & - & . & - & . \\
\hline
\end{tabular}


Table 1 (continued)

\begin{tabular}{|c|c|c|c|c|c|c|c|c|}
\hline \multirow[b]{2}{*}{ Column } & \multicolumn{6}{|c|}{ A } & \multicolumn{2}{|c|}{$\mathrm{B}$} \\
\hline & 1 & & & 2 & 3 & 4 & 5 & 6 \\
\hline Sphagnum fimbriatum & - & & - & 10 & - & - & - & - \\
\hline Cladonia deformis & - & & - & 10 & - & - & - & - \\
\hline Dibaeis baeomyces & - & & - & 10 & - & - & - & - \\
\hline Drepanocladus uncinatus & - & & - & 10 & - & - & - & - \\
\hline Pogonatum urnigerum & - & & - & 10 & - & - & - & - \\
\hline Paraleucobryum longifolium & - & . & - & 10 & - & - & - & - \\
\hline Racomitrium heterostichum & - & & - & 10 & - & - & - & - \\
\hline Distichium capillaceum & - & . & - & 10 & - & - & - & - \\
\hline Cynodontium polycarpon & - & & - & 10 & - & - & - & - \\
\hline Pohlia nutans & - & . & - & 10 & - & - & - & - \\
\hline Anomodon attenuatus & - & . & - & 10 & - & - & - & - \\
\hline Plagiothecium cavifolium & - & . & - & 10 & - & - & - & - \\
\hline Bartramia halleriana & - & . & - & 10 & - & - & - & - \\
\hline Geocalyx graveolens & - & & - & 10 & - & - & - & - \\
\hline Fossombronia sp. & - & & - & 10 & - & - & - & - \\
\hline Lophozia sp. & - & 2 & - & 10 & - & - & - & - \\
\hline Sphagnum sp. & - & & - & 10 & - & - & - & - \\
\hline
\end{tabular}

spruce communities (class Piceetea excelsae Klika 1948) into two groups in the syntaxonomic rank of an order (and their respective alliances): Piceetalia excelsae Pawłowski ex Pawłowski et al. 1928 (non-carbonate section) and Athyrio filicis-feminae-Piceetalia Hadač ex Hadač et al. 1969 (carbonate section) (Kučera 2012).

Comprehensive comparison of supramontane Norway spruce vs. Arolla pine communities of the Western Carpathians was published by Kučera (2012); however, non-carbonate Arolla pine communities were not studied in a more detailed way and only one association was distinguished (i.e. CembroPiceeetum Myczkowski et Lesiński 1974).

Floristic differences in the field layer of Arolla pine vs. Norway spruce communities are obviously more visible in carbonate phytocoenoses which commonly have numerous species lists (Kučera 2012, tab. 2: Sesleria tatrae, Rhodiola rosea, Cystopteris montana, Dactylorhiza fuchsii ssp. fuchsii etc.). On the other hand, poor floristic composition of non-carbonate phytocoenoses does not allow such clear separation, although some of the non-carbonate units 
have unique features in contrast with the corresponding group of Norway spruce woodlands; e.g., Vaccinium gaultherioides, Listera cordata, Empetrum nigrum agg. (Myczkowski and Lesiński 1974) or unusually rich ground layer flora of phytocoenoses (records by Barančok and Varšavová 1995). Also, the presence of Juniperus sibirica in the understorey of some Arolla pine woodlands should be noted.

The most characteristic sign of Arolla pine communities is their distinct physiognomy formed by the presence (dominance) of Pinus cembra and special spatial appearance originating from specific biogeographical position of Arolla pine woodlands in the Western Carpathians. P. cembra is accompanied by Betula carpatica and Larix decidua (population strongly reduced by historical human impact), which are absent in supramontane Picea abies communities of the Western Carpathians mountain ranges.

Following phytocoenotic and ecological differences, I exclude Arolla pine woodlands from alliance syntaxa of Norway spruce woodlands (i.e., Piceion excelsae Pawłowski ex Pawłowski et al. 1928 and Oxalido-Piceion Hadač et al. 1969) and differentiate two syntaxa in the rank of alliance, which are non-carbonate Homogyno alpinae-Pinion cembrae P. Kučera 2017 and carbonate Calamagrostio variae-Pinion cembrae P. Kučera 2017. Geological bedrock related division of Arolla pine phytocoenoses was published by Barančok (2002) already; however, that author differentiated the two mentioned basic groups within Cembro-Piceetum at the ranks of subassociation.

Rübel (1933) was probably the first to properly recognize the separate status of Arolla pine woodlands. He distinguished a separate order "Cembretalia", and the corresponding alliance was named "Cembrion oder Laricion" - thus none of these two names was definitely adopted by the author (ICPN Art. 3b). All three names were published as nomina nuda (Art. 2b) by Rübel (1933). The next author who differentiated a corresponding phytoceonological unit was Gams (1936); however, he used ranks "union" and "consociation" (Cembreta, Cembrion) which are not ruled by the ICPN (Principle II, Weber et al. 2000).

The name "Cembro-Laricion Gams 1936, nom. nudum" used by Eggler (1952) is a nomen fictum (see above). Lately, Rivas-Martínez (Rivas-Martínez et al. 2011) proposed de novo a separate alliance for Arolla pine woodlands Pinion cembrae Rivas-Martínez in Rivas-Martínez et al. (2011). This name's validity is also questionable: see the Nomenclatural appendix at the end of this paper.

The syntaxonomical position of the mentioned alliance names is disputable: only the last one (Pinion cembrae Rivas-Martínez in Rivas-Martínez et al. 2011) was supplemented with a reference to some relevé data. Direct and indirect referring (Rivas-Martínez et al. 2011, p. 457) to data of Pallman and Hafter (1933) justify seeing the intended syntaxonomical content of Pinion cembrae Ri- 
vas-Martínez in Rivas-Martínez et al. 2011 as a parallel (i.e., Alpine non-carbonate phytocoenoses) to Western Carpathians's alliance Homogyno alpinae-Pinion cembrae P. Kučera 2017. If a comprehensive evaluation of Alpine non-carbonate Arolla pine syntaxa should confirm a distinct floristical character of Alpine units, one of above-mentioned names should be properly validated.

Syntaxonomical overview of the higher syntaxa of Piceetea excelsae Klika 1948 in the Western Carpathians with enumeration of Arolla pine associations

Piceetalia excelsae Pawłowski ex Pawłowski et al. 1928 Piceion excelsae Pawłowski ex Pawłowski et al. 1928 Homogyno alpinae-Pinion cembrae P. Kučera 2017 Homogyno alpinae-Pinetum cembrae P. Kučera 2017 Prenantho purpureae-Pinetum cembrae P. Kučera 2017 Mylio taylorii-Pinetum cembrae P. Kučera 2017 Cembro-Piceetum Myczkowski et Lesiński 1974 Athyrio filicis-feminae-Piceetalia Hadač ex Hadač et al. 1969 Oxalido-Piceion Hadač et al. 1969 Calamagrostio variae-Pinion cembrae P. Kučera 2017 Seslerio tatrae-Pinetum cembrae P. Kučera 2017 Cystopterido montanae-Pinetum cembrae P. Kučera 2017

\section{DESCRIPTION OF SYNTAXA OF AROLLA PINE WODLANDS OF THE WESTERN CARPATHIANS}

\section{Homogyno alpinae-Pinion cembrae P. Kučera 2017, all. nova hoc loco}

Original diagnosis: Homogyno alpinae-Pinetum cembrae P. Kučera 2017 ass. nova, Prenantho purpureae-Pinetum cembrae P. Kučera 2017 ass. nova, Mylio taylorii-Pinetum cembrae P. Kučera 2017 ass. nova, Cembro-Piceetum Myczkowski et Lesiński 1974.

Nomenclatural type: Homogyno alpinae-Pinetum cembrae P. Kučera 2017 ass. nova, holotypus hoc loco.

Differential species $(\phi(\times 100) \geq 25)$ compared to Calamagrostio variae-Pinion cembrae:

$\mathrm{E}_{3}:-$,

$\mathrm{E}_{2}:-$,

$\mathrm{E}_{1}$ : Calamagrostis villosa (67), Avenella flexuosa (36), Vaccinium myrtillus (33),

$\mathrm{E}_{0}$ : Calypogeia integristipula (49), Sphagnum girgensohnii (43). 
The alliance Homogyno alpinae-Pinion cembrae comprises non-carbonate Arolla pine forest phytocoenoses. Commonly species poor composition of field and ground layers almost does not, more or less, allow positive differentiation of this group of forest communities: within the dataset evaluated in this paper, only three of the abundant species are limited to Homogyno alpinaePinion cembrae - Calamagrostis villosa, Calypogeia integristipula and Sphagnum girgensohnii. In addition, species of phytocoenoses with more abundant taxa list (Calamagrostis arundinacea, Soldanella hungarica, Gymnocarpium dryopteris etc.) are not exclusively bound to Homogyno alpinae-Pinion cembrae as they grow also in Calamagrostio variae-Pinion cembrae phytocoenoses. Low representation of species like Cicerbita alpina, Doronicum austriacum and Ranunculus platanifolius within the latter alliance is likely due to the small number of published relevés as of now.

Records of Homogyno alpinae-Pinion cembrae were published from various parts of the High Tatras (mostly from Slovakia, Poland) and also from the West Tatras (Slovakia) where the original distribution of Arolla pine forests was especially strongly reduced by human impact in the past.

Woodlands with the Arolla pine on the non-carbonate bedrock are also referred from other European countries. Analogous syntaxa to here described Tatras' associations were published from: - Romania (Coldea et al. 2015): Rhododendro myrtifolii-Pinetum cembrae (Borza 1934) Coldea in Coldea et al. 2015*; - Austria (Karner 2007): Larici-Pinetum cembrae Ellenberg et Klötzli 1972*, Cotoneastro-Pinetum cembrae Béguin et Theurillat 1982; - Germany (Seibert 1992): Larici-Pinetum cembrae Ellenberg et Klötzli 1972*; - Switzerland (Ellenberg and Klötzli 1972, Keller et al. 1998): Larici-Pinetum cembrae Ellenberg et Klötzli 1972 [and Cotoneastro integerrimae-Pinetum cembrae Béguin et Theurillat 1982 (see Béguin and Theurillat 1982)]; - France (Bardat et al. 2011): Larici-Pinetum cembrae Ellenberg et Klötzli 1972*, Cotoneastro-Pinetum cembrae Béguin et Theurillat 1982.

\subsection{Homogyno alpinae-Pinetum cembrae P. Kučera, ass. nova hoco}

Original diagnosis: Vidličková (1989), p. 64-65, tab. 1, rel. 1-16.

Nomenclatural type: Vidličková (1989), p. 64-65, tab. 1, rel. 13, holotypus hoc loco.

Corresponding name: Piceetum excelsae myrtilletosum Pawłowski et al. 1928 facies with Pinus cembra

Characteristic species combination:

A) differential species $(\phi(\times 100) \geq 20)$ :

$\mathrm{E}_{1}$ : Avenella flexuosa (28), Rubus idaeus (20),

$\mathrm{E}_{0}$ : Plagiomnium affine (28);

* See the Nomenclatural appendix at the end of the paper. 
B) constant species (constancy $\geq 50 \%$ ):

$\mathrm{E}_{3}$ : Pinus cembra (100), Picea abies (98),

$\mathrm{E}_{2}:-$,

$\mathrm{E}_{1}$ : Sorbus aucuparia (89), Vaccinium myrtillus (100), Avenella flexuosa (97), Dryopteris dilatata (89), Homogyne alpina (83), Oxalis acetosella (82), Vaccinium vitis-idaea (65), Calamagrostis villosa (62), Rubus idaeus (62), Luzula sylvatica (55), L. luzuloides (55),

$\mathrm{E}_{0}$ : Dicranum scoparium (91), Polytrichum formosum (54).

Association Homogyno alpinae-Pinetum cembrae represents most commonly recorded Arolla pine woodland of the Tatras. The community is characteristic by poor floristical composition with the number of field layer species not exceeding 20 (often below 10-15) and the number of ground layer species mostly up to 10 . Some authors have published less than 5 records of bryophyte taxa; occasionally, bryophytes grow within the relevé plot on rocks only. Stands are in the field layer usually dominated by Vaccinium myrtillus or Calamagrostis villosa, higher cover-abundance values are often reached by Avenella flexuosa, Homogyne alpina, Oxalis acetosella, Dryopteris dilatata. Rarely codominant species are Adenostyles alliariae or Luzula sylvatica.

This plant community is the basic and most spread unit of Arolla pine woodlands of the Western Carpathians, distributed on the non-carbonate bedrock in the High Tatras as well as in the West Tatras: recent remnants of the uppermost forest horizon in the Tatras are for the most part formed by this association.

Myczkowski and Lesiński (1974, tab. 2, col. 4) recorded a relevé of phytocoenosis related to Homogyno alpinae-Pinetum cembrae also on limestone; however, it is questionable if the stand represents a stable plant community with a stabilized plant species composition that is free of anthropogeneous influence in the past two centuries. Further research of this site is needed, especially considering the presence of Corallorhiza trifida and Listera cordata (or Moneses uniflora).

On the ground of habitat induced floristical variability of the association's relevés, two subgroups of phytocoenoses are distinguished here and evaluated in the rank of subassociation:

\subsubsection{Homogyno alpinae-Pinetum cembrae typicum P. Kučera 2017, subass. nova hoco}

Original diagnosis: Vidličková (1989), p. 64-65, tab. 1, rel. 1-16.

Nomenclatural type: Vidličková (1989), p. 64-65, tab. 1, rel. 13, holotypus hoc loco.

The subassociation contains typically developed phytocoenoses of the association. 
Data: Pawłowski et al. (1928): tab. 12, rel. 4; Krajina (1933): tab. 69, rel. 10; Horák (1971): tab. 1, rel. 8; Myczkovski and Lesiński (1974): tab. 5, column 4; Kobzáková (1987): tab. 6, rel. 14; Moravčíková (1987): tab. 4, rel. 6, 10-13, 22; tab. 6, rel. 6-8, 15, 16, 18; tab. 7, rel. 2, 18; Nad'ová (1987): tab. 1, rel. 10; tab. 3, rel. 1; Rajcová (1987): tab. I.1, rel. 2, 3, 27, 29, 32, 35, 39; tab. I.2 (10 rel.); tab. I.3, rel. 5; tab. I.5, rel. 6, 7; Vidličková (1989): tab. 1 (16 relevés); Kubíček et al. (1992): tab. 1, rel. 1; Valachovič (2014): tab. 1, rel. 6.

\subsubsection{Homogyno alpinae-Pinetum cembrae cladonietosum digitatae P. Kučera 2017, subass. nova hoco}

Original diagnosis: Valachovič (2014), p. 23-24, tab. 1, rel. 1-5.

Nomenclatural type: Valachovič (2014), p. 23-24, tab. 1, rel. 5, holotypus hoc loco.

In this subassociation are included floristically separate phytocoenoses of the association Homogyno alpinae-Pinetum cembrae, defined by the constant presence of species of genus Cladonia (C. digitata, C. squamosa, C. sulphurina etc.) which are absent in the subasociation typicum. In the evaluated dataset, they are accompanied by a constant presence of Hylocomium splendens with cover-abundances (+) 1-2. Until now, Gentiana punctata was recorded only in this group within the association. Due to a limited cover of the canopy layer, Pinus mugo is constantly present and reaches high cover-abundance values $(2-4)$.

Data: Horák (1971): tab. 1, rel. 9; Valachovič (2014): tab. 1, rel. 1-5.

\subsection{Prenantho purpureae-Pinetum cembrae P. Kučera, ass. nova hoco}

Original diagnosis: see Table 2.

Nomenclatural type: Horák (1971), tab. 1., rel. 10, holotypus hoc loco.

Characteristic species combination:

A) differential species $(\phi(\times 100) \geq 25)$ :

$\mathrm{E}_{3}:-$,

$\mathrm{E}_{2}:-$

$\mathrm{E}_{1}$ : Juniperus sibirica (44), Lonicera nigra (36), Cicerbita alpina (51), Gentiana asclepiadea (50), Athyrium filix-femina (46), Prenathes purpurea (42), Aconitum firmum ssp. firmum (41), Galeobdolon montanum (41), Phegopteris connectilis (38), Ranunculus platanifolius (34), Doronicum austriacum (33), Veratrum album ssp. lobelianum (32), Calamagrostis arudinacea (25), Adenostyles alliariae (25), 
Table 2

Original diagnosis of Prenantho purpureae-Pinetum cembrae P. Kučera 2017 ass. nova. $\phi$-values $(\times 100)$ are adopted from the Table 1. Relevé data: Rel. 1: Moravčíková (1987): tab. 4, rel. 17; Rel. 2: Nad’ová (1987): tab. 3, rel. 5; Rel. 3: Krajina (1933): tab. 61, rel. 6; Rel. 4: Šoltés (1976): tab. 4, rel. 10; Rel. 5: Kukla et al. (2004): tab. 4, rel. of "monitoring plot J"; Rel. 6: Horák (1971): tab. 1., rel. 10; Rel. 7: Barančok and Varšavová (1995): tab. 1, rel. 13; Rel. 8: Barančok and Varšavová (1995): tab. 1, rel. 16; Rel. 9: Barančok and Varšavová (1995): tab. 1, rel. 17; Rel. 10: Barančok and Varšavová (1995): tab. 1, rel. 5

\begin{tabular}{|c|c|c|c|c|c|c|c|c|c|c|c|}
\hline \multirow[t]{2}{*}{ Relevé No. } & & 1 & 2 & 3 & 4 & 5 & 6 & 7 & 8 & 9 & 10 \\
\hline & \multicolumn{11}{|l|}{$\phi$} \\
\hline \multicolumn{12}{|c|}{ Tree and shrub species } \\
\hline \multicolumn{12}{|c|}{$\mathrm{E}_{3}$} \\
\hline Picea abies & - & 4 & 4 & 5 & 3 & 4 & 2 & 4 & 4 & 4 & 2 \\
\hline Pinus cembra & - & 1 & $\mathrm{r}$ & $\mathrm{r}$ & + & 1 & 3 & 3 & 3 & 3 & 3 \\
\hline Sorbus aucuparia & - & . & . & . & 3 & . & . & + & + & 1 & 2 \\
\hline Larix decidua & - & . & . & $\mathrm{r}$ & + & . & 1 & . & . & . & . \\
\hline \multicolumn{12}{|l|}{$\mathrm{E}_{2}$} \\
\hline Picea abies & - & . & . & 1 & . & 2 & + & + & + & 3 & + \\
\hline Sorbus aucuparia & - & . & . & . & . & 2 & + & 2 & + & 2 & . \\
\hline Pinus mugo & - & . & . & . & . & . & 2 & 3 & + & . & 3 \\
\hline Salix silesiaca & 6 & . & . & . & . & . & . & 1 & $\mathrm{r}$ & + & $\mathrm{r}$ \\
\hline Pinus cembra & - & . & . & + & . & . & . & + & . & + & . \\
\hline Larix decidua & - & . & . & $\mathrm{r}$ & . & . & . & . & . & . & . \\
\hline Ribes petraeum & - & . & . & . & . & . & . & . & $\mathrm{r}$ & . & . \\
\hline \multicolumn{12}{|l|}{$\mathbf{E}_{1}$} \\
\hline Sorbus aucuparia & - & + & 1 & $\mathrm{r}$ & . & 2 & + & 1 & 1 & 1 & + \\
\hline Lonicera nigra & 36 & . & . & . & + & . & + & + & $\mathrm{r}$ & + & $\mathrm{r}$ \\
\hline Picea abies & - & . & + & . & . & 1 & + & . & + & + & . \\
\hline Pinus cembra & - & . & . & $\mathrm{r}$ & $\mathrm{r}$ & . & + & + & . & . & . \\
\hline Juniperus sibirica & 44 & . & . & . & . & . & 3 & $\mathrm{r}$ & . & + & . \\
\hline Ribes petraeum & 8 & . & . & . & . & . & + & $\mathrm{r}$ & . & $\mathrm{r}$ & . \\
\hline Pinus mugo & - & . & . & . & . & . & 2 & . & . & . & . \\
\hline Larix decidua & - & . & . & . & . & . & + & . & . & . & . \\
\hline Rosa pendulina & - & . & . & . & . & . & + & . & . & . & . \\
\hline Salix silesiaca & - & . & . & . & . & . & . & + & . & . & . \\
\hline Salix caprea & - & . & . & . & . & . & . & $\mathrm{r}$ & . & . & . \\
\hline
\end{tabular}


Table 2 (continued)

\begin{tabular}{llllllllllll}
\hline Relevé No. & & 1 & 2 & 3 & 4 & 5 & 6 & 7 & 8 & 9 & 10 \\
\hline & $\phi$ & & & & & & & & & & \\
\hline
\end{tabular}

\section{Differential ground layer species $\left(\mathrm{E}_{1}\right)$}

Cicerbita alpina

Gentiana asclepiadea

Athyrium filix-femina

51

51

Prenanthes purpurea

Aconitum firmum ssp. firmum

Galeobdolon montanum

Phegopteris connectilis

$\begin{array}{lllllllll}50 & \cdot & + & \cdot & \mathrm{r} & + & 1 & + & 1 \\ 46 & \mathrm{r} & 1 & \cdot & + & \cdot & + & \cdot & 3\end{array}$

Ranunculus platanifolius

Senecio nemorensis agg.

Doronicum austriacum

Veratrum album ssp. lobelianum

Calamagrostis arundinacea

42

Adenostyles alliariae

$\begin{array}{lll}- & 1 & + \\ 33 & r & + \\ 32 & \cdot & \cdot \\ 25 & 2 & + \\ 25 & 4 & 3\end{array}$

Differential ground layer species $\left(\mathrm{E}_{0}\right)$

Blepharostoma trichophyllum

Brachythecium velutinum

Cladonia squamosa var. subsquamosa

Bazzania tricrenata

Rhytidiadelphus triquetrus

Other field layer species $\left(\mathrm{E}_{1}\right)$

Oxalis acetosella

Vaccinium myrtillus

Dryopteris dilatata

Avenella flexuosa

Calamagrostis villosa

Homogyne alpina

Vaccinium vitis-idaea

Luzula luzuloides

Gymnocarpium dryopteris

$\begin{array}{rrrrrrrrrrr}- & 1 & 3 & 3 & 1 & 2 & 2 & 1 & 2 & 1 & 1\end{array}$

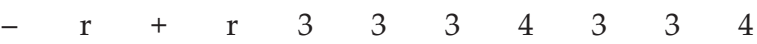

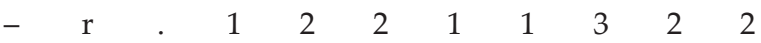

$\begin{array}{llllllllll}- & \mathrm{r} & . & 1 & 2 & 2 & 2 & 2 & 1 & +\end{array}$

-
- $\quad \begin{array}{ccccccc}1 & 1 & 2 & 3 & 3 & 3\end{array}$

Luzula sylvatica

$\begin{array}{llllllllll}- & \cdot & \mathrm{r} & 2 & 2 & 3 & 1 & 1 & + & 2\end{array}$

- . . $1+$. $11++$

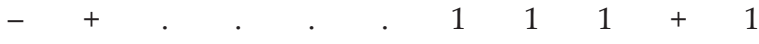

$24.1+. \quad 1.5 . \quad+1$

$-\quad . \quad . \quad 1 \quad 2+1$. 1


Table 2 (continued)

\begin{tabular}{|c|c|c|c|c|c|c|c|c|c|c|c|}
\hline \multirow[t]{2}{*}{ Relevé No. } & & 1 & 2 & 3 & 4 & 5 & 6 & 7 & 8 & 9 & 10 \\
\hline & \multicolumn{11}{|l|}{$\phi$} \\
\hline Rubus idaeus & - & . & . & + & . & + & . & + & + & + & . \\
\hline Huperzia selago & - & . & . & . & . & + & . & 2 & 1 & 1 & + \\
\hline Solidago virgaurea & - & $\mathrm{r}$ & . & . & . & . & + & + & + & . & . \\
\hline Lycopodium annotinum & - & . & . & . & + & 1 & . & . & . & 3 & + \\
\hline Soldanella hungarica & - & . & + & . & . & $\mathrm{r}$ & . & . & $\mathrm{r}$ & . & . \\
\hline Hieracium murorum & - & . & . & $\mathrm{r}$ & $\mathrm{r}$ & . & . & . & $\mathrm{r}$ & . & . \\
\hline Gentiana punctata & - & . & . & . & . & . & . & + & $\mathrm{r}$ & . & 1 \\
\hline Polygonatum verticillatum & - & . & 1 & . & . & . & + & . & . & . & . \\
\hline Campanula tatrae ssp. tatrae & - & . & . & . & . & . & + & + & . & . & . \\
\hline \multicolumn{12}{|c|}{ Other ground layer species $\left(\mathrm{E}_{0}\right)$} \\
\hline Dicranum scoparium & - & . & + & 1 & 2 & 2 & 3 & 1 & + & 4 & 3 \\
\hline Polytrichum formosum & - & . & + & + & 1 & 2 & + & 2 & 1 & 2 & 4 \\
\hline Hylocomium splendens & 20 & . & 1 & 1 & + & . & 1 & 1 & + & 2 & $\mathrm{r}$ \\
\hline Plagiothecium curvifolium & - & + & . & . & . & . & . & + & + & + & + \\
\hline Pleurozium schreberi & - & . & . & . & 2 & . & 2 & . & . & $\mathrm{r}$ & 1 \\
\hline Lophozia ventricosa & - & . & . & . & . & . & + & . & $\mathrm{r}$ & + & 1 \\
\hline Calypogeia integristipula & - & . & . & . & + & . & . & . & 1 & . & 1 \\
\hline Plagiothecium undulatum & - & . & . & . & . & 1 & . & . & . & 1 & 1 \\
\hline Hypnum cupressiforme & - & . & . & . & . & . & + & + & + & . & . \\
\hline Cladonia chlorophaea & - & . & . & . & . & . & + & $\mathrm{r}$ & . & . & + \\
\hline Dicranella heteromalla & - & . & . & . & . & . & . & + & + & 1 & . \\
\hline Sphagnum girgensohnii & - & . & . & . & . & . & . & + & . & 2 & 4 \\
\hline Mylia taylorii & - & . & . & . & . & . & . & . & + & 2 & 2 \\
\hline Cladonia gracilis & - & . & . & $\mathrm{r}$ & . & . & + & . & . & . & . \\
\hline Ptilidium ciliare & - & . & . & $\mathrm{r}$ & . & . & . & + & . & . & . \\
\hline Polytrichum juniperinum & - & . & . & $\mathrm{r}$ & . & . & . & . & . & . & + \\
\hline Cladonia digitata & - & . & . & . & . & . & + & $\mathrm{r}$ & . & . & . \\
\hline Cladonia rangiferina & - & . & . & . & . & . & + & . & . & . & $\mathrm{r}$ \\
\hline Cetraria islandica & - & . & . & . & . & . & . & + & + & . & . \\
\hline Racomitrium microcarpon & - & . & . & . & . & . & . & + & . & . & 1 \\
\hline Barbilophozia lycopodioides & - & . & . & . & . & . & . & + & . & . & + \\
\hline Barbilophozia attenuata & - & . & . & . & . & . & . & + & . & . & + \\
\hline
\end{tabular}


Table 2 (continued)

\begin{tabular}{lllllllllllll}
\hline Relevé No. & & 1 & 2 & 3 & 4 & 5 & 6 & 7 & 8 & 9 & 10 \\
\hline & $\phi$ & & & & & & & & & & \\
\hline Ditrichum heteromallum & - &. &. &. &. &. &. & r & + &. &. \\
Calypogeia azurea & - &. &. &. &. &. &. & &. & 1 &. & + \\
Diplophyllum taxifolium & - &. &. &. &. &. &. &. & + &. & + \\
\hline
\end{tabular}

Field and ground layer species in only one relevé:

Rel. 1: $\mathrm{E}_{1}$ - Stellaria nemorum 2, Leucanthemum rotundifolium 1, Chaerophyllum hirsutum 1, Myosotis scorpioides +; $\mathrm{E}_{0}-$ Mnium spinosum 1;

Rel. 2: $\mathrm{E}_{1}$-Dryopteris carthusiana 1, D. filix-mas 1;

Rel. 3: $\mathrm{E}_{1}$ - Paris quadrifolia + , Epilobium angustifolium $\mathrm{r}$, Moneses uniflora $\mathrm{r}$, Selaginella selaginoides $\mathrm{r} ; \mathrm{E}_{0}-$ Entodon schleicheri 1, Hylocomium umbratum 1, Polytrichum longisetum 1, Ptilium crista-castrensis 1, Sphagnum fimbriatum +, Cladonia deformis $\mathrm{r}$, Dibaeis baeomyces $r$, Drepanocladus uncinatus r;

Rel. 4: $\mathrm{E}_{1}$ - Mycelis muralis $\mathrm{r}$; $\mathrm{E}_{0}$ - Lophozia sp. +, Plagiothecium denticulatum +, Ptilidium pulcherrimum +;

Rel. 5: $\mathrm{E}_{1}$ - Athyrium distentifolium 2, Ligusticum mutellina +, Streptopus amplexifolius +; $\mathrm{E}_{0}$ - Sphagnum sp. 1, Rhizomnium punctatum r;

Rel. 6: $\mathrm{E}_{1}$ - Ranunculus platanifolius 1, Soldanella carpatica 1, Galium schultesii +, Geranium sylvaticum + , Hieracium bifidum +, H. lachenalii +, Hylotelephium argutum +, Jovibarba globifera ssp. glabrescens + , Lilium martagon + , Melampyrum sylvaticum + , Potentilla aurea + , Phyteuma spicatum + , Valeriana tripteris + , Calluna vulgaris $\mathrm{r}$, Crepis conyzifolia $\mathrm{r}$; $\mathrm{E}_{0}-$ Dicranum montanum 1, Paraleucobryum longifolium 1, Pogonatum urnigerum 1, Racomitrium heterostichum 1, Tetraphis pellucida 1, Anomodon attenuatus + , Bartramia halleriana + , Calypogeia neesiana + , Cynodontium polycarpon + , Distichium capillaceum + , Plagiothecium cavifolium + , Pohlia nutans + , Polytrichum commune +;

Rel. 7: $\mathrm{E}_{1}$ - Oreochloa disticha 1;

Rel. 8: $\mathrm{E}_{0}$ - Geocalyx graveolens +, Dicranoweisia crispula r;

Rel. 9: $\mathrm{E}_{1}$ - Polypodium vulgare $\mathrm{r} ; \mathrm{E}_{0}$ - Bazzania trilobata 2;

Rel. 10: $\mathrm{E}_{0}$ - Lepidozia reptans 1, Cladonia coccifera +, Fossombronia sp. +, Anastrepta orcadensis $\mathrm{r}$, Lophozia sudetica $\mathrm{r}$.

$\mathrm{E}_{0}$ : Blepharostoma trichophyllum (42), Brachythecium velutinum (41), Cladonia squamosa var. subsquamosa (Nyl. ex Leight.) Vain. (37), Bazzania tricrenata (29), Rhytidiadelphus triquetrus (29);

B) constant species (constancy $\geq 50 \%$ ):

$\mathrm{E}_{3}$ : Picea abies (100), Pinus cembra (100), Sorbus aucuparia (50),

$\mathrm{E}_{2}$ : Picea abies (70), Sorbus aucuparia (50), Picea abies (50),

$\mathrm{E}_{1}$ : Sorbus aucuparia (90), Lonicera nigra (60), 
Oxalis acetosella (100), Vaccinium myrtillus (100), Dryopteris dilatata (90), Avenella flexuosa (90), Calamagrostis villosa (80), Homogyne alpina (80), Prenanthes purpurea (80), Adenostyles alliariae (70), Gentiana asclepiadea (70), Vaccinium vitis-idaea (70), Veratrum album ssp. lobelianum (60), Luzula sylvatica (60), Gymnocarpium dryopteris (60), L. luzuloides (60), Cicerbita alpina (50), Huperzia selago (50), Athyrium filix-femina (50), Calamagrostis arundinacea (50), Rubus idaeus (50),

$\mathrm{E}_{0}$ : Polytrichum formosum (90), Dicranum scoparium (90), Hylocomium splendens (80), Rhytidiadelphus triquetrus (50), Blepharostoma trichophyllum (50), Bazzania tricrenata (50), Plagiothecium curvifolium (50).

The association Prenantho purpureae-Pinetum cembrae represents group of Arolla pine non-carbonate phytocoenoses with usually moderately rich field layer composition; the number of ground layer taxa is variable - partly rich as well. Higher cover-abundance is constantly reached by Oxalis acetosella, while Vaccinium myrtillus/Calamagrostis villosa, Dryopteris dilatata, Avenella flexuosa, Homogyne alpina are (mostly) dominating. The group of more nutrient demanding species is the characteristic feature of this Arolla pine community: Prenanthes purpurea, Gentiana asclepiadea, Adenostyles alliariae, Cicerbita alpina, Doronicum austriacum. Calamagrostis arundinacea, Athyrium filix-femina or Luzula sylvatica could be in abundance. Shrub species Lonicera nigra and Ribes petraeum were frequently recorded.

Stands of Prenantho purpureae-Pinetum cembrae were recorded in the West Tatras as well as the High Tatras. At the moment, this association comprises a slightly heterogeneous group of non-carbonate phytocoenoses: the reason is that a rather small amount of relevés have been recorded to the present. Specialised field research should be performed to define actual spatial distribution, ecological factors determining development of this Arolla pine woodland and the general pattern of species composition.

Questionable is classification of the rel. 17 and especially the rel. 5 of Barančok and Varšavová (1995, Tab. 1) within this association, as they represent a type of transition to the next association; however, the presence of Adenostyles alliariae, Prenanthes purpurea, Gymnocarpium dryopteris etc., was the reason of this classification.

Data: Krajina (1933): tab. 61, rel. 6; Horák (1971): tab. 1., rel. 10; Šoltés (1976): tab. 4, rel. 10; Moravč́́ková (1987): tab. 4, rel. 17; Nad’ová (1987): tab. 3, rel. 5; Barančok and Varšavová (1995): tab. 1, rel. 5, 13, 16, 17; Kukla et al. (2004): tab. 4, rel. of "monitoring plot J".

\subsection{Mylio taylorii-Pinetum cembrae P. Kučera, ass. nova hoco}

Original diagnosis: Barančok et Varšavová (1995), p. 45-48, tab. 1, rel. $1-4,6-12,14,15,18-24$. 
Nomenclatural type: Barančok et Varšavová (1995), p. 45-48, tab. 1, rel. 22, holotypus hoc loco.

Corresponding name: Cembro-Piceetum [ut Pino cembrae-Piceetum] typicum Barančok 2002 pro parte min., nom. inval. (Art. 2b).

Characteristic species combination:

A) differential species $(\phi(\times 100) \geq 25)$ :

$\mathrm{E}_{2}$ : Pinus mugo (27),

$\mathrm{E}_{1}$ : Lycopodium annotinum (37),

$\mathrm{E}_{0}$ : Lophozia ventricosa (75), Sphagnum girgensohnii (75), Mylia taylorii (67), Dicranoweisia crispula (67), Dicranella heteromalla (64), Cladonia coccifera (63), Bazzania tricrenata (62), Cladonia chlorophaea (60), Barbilophozia attenuata (56), Calypogeia integristipula (55), Cetraria islandica (55), Racomitrium microcarpon (53), Ditrichum heteromallum (53), Lophozia sudetica (50), Racomitrium lanuginosum (46), Cladonia gracilis (44), Barbilophozia lycopodioides (43), Diplophyllum taxifolium (43), Polytrichum formosum (36), Pohlia elongata (35), Cladonia rangiferina (35), Calypogeia azurea (34), Plagiothecium curvifolium (33), Chiloscyphus pallescens (33), Blepharostoma trichophyllum (42), Cladonia pyxidata (29), Barbilophozia floerkei (29), Pleurozium schreberi (28), Dicranum scoparium (26), Bazzania trilobata (26), Cladonia digitata (25);

B) constant species (constancy $\geq 50 \%$ ):

$\mathrm{E}_{3}$ : Pinus cembra (100), Picea abies (100), Sorbus aucuparia (65),

E: Picea abies (100), Pinus mugo (90), Sorbus aucuparia (70), Pinus cembra (50),

E: Sorbus aucuparia (100), Picea abies (60), Pinus cembra (50), Vaccinium myrtillus (100), Vaccinium vitis-idaea (95), Avenella flexuosa (95), Lycopodium annotinum (80), Dryopteris dilatata (75), Huperzia selago (75), Homogyne alpina (75), Oxalis acetosella (70), Calamagrostis villosa (50),

$\mathrm{E}_{0}$ : Dicranum scoparium (100), Polytrichum formosum (100), Mylia taylorii (95), Lophozia ventricosa (95), Sphagnum girgensohnii (95), Bazzania tricrenata (80), Calypogeia integristipula (75), Hylocomium splendens (75), Dicranella heteromalla (70), Plagiothecium curvifolium (70), Pleurozium schreberi (65), Cladonia chlorophaea (65), Cetraria islandica (65), Dicranoweisia crispula (60), Cladonia coccifera (55), Barbilophozia attenuata (55), Ditrichum heteromallum (50), Racomitrium microcarpon (50).

Floristical composition and overall characteristics of phytocoenoses belonging to Mylio taylorii-Pinetum cembrae was published by Barančok and Varšavová (1995). Except for an almost constant presence of Pinus mugo in the understorey, phytocoenoses are notable for their unusually rich ground layer flora with high cover-abundance. Constant and dominating are Dicranum scoparium, Polytrichum formosum, Sphagnum girgensohnii and Mylia taylorii. These species are constantly accompanied by bryophytes Bazzania tricrenata, Calypogeia integristipula, Hylocomium splendens, Dicranella heteromalla etc., as well as by frequent lichenes Cetraria islandica, Cladonia chlorophaea and other Cladonia species.

On the other hand, the number of field layer species is small - mostly not exceeding 10 species. The presence of Lycopodium annotinum is a typical characteristic; the dominating field layer species are commonly Vaccinium myrtillus, Avenella flexuosa, and V. vitis-idaea. Phytocoenoses of the richer field layer species composition could be distinguished as the association variant (1) with 
Rubus idaea (Dryopteris filix-mas, Luzula luzuloides, and absence or low abundance of Lycopodium annotinum, Sphagnum girgensohnii; Barančok et al. 1995, rel. 8, 10, 14, 15) and (2) typical variant.

Until now, records of this community are known only from the Bielovodská dolina in the northeastern part of non-carbonate High Tatras (cf. Barančok and Varšavová 1995).

Characteristic attribute of Mylio taylorii-Pinetum cembrae phytocoenoses is usually high ground layer cover $\left(\mathrm{E}_{0}\right.$ cover $50-60 \%$ and more) and rich abundance of Sphagnum girgensohnii. Only relevés 14 and 15 of the original diagnosis (Barančok and Varšavová 1995, tab. 1) differ in a distinct way $\left(\mathrm{E}_{0}\right.$ cover 30 and 5\%, Sphagnum cover-abundance negative and "+"); also, the last mentioned relevé has a higher number of field layer species.

Valachovič (2014) ascribes a boreal character to the forests of the distribution area of Mylio taylorii-Pinetum cembrae (Barančok and Varšavová 1995). By contrast, occurrence (dominance) of Pinus cembra s. str. with P. mugo s. str. as well as Homogyne alpina (cf. Barančok and Varšavová 1995) strictly determine prevailingly Alpine-Carpathian character of Mylio taylorii-Pinetum cembrae woodlands.

Data: Barančok and Varšavová (1995): tab. 1, rel. 1-4, 6-12, 14, 15, 18-24.

\subsection{Cembro-Piceetum Myczkowski et Lesiński 1974}

Original diagnosis: Myczkovski and Lesiński (1974), p. 41-43, tab. 4.

Nomenclatural type: Myczkovski and Lesiński (1974), p. 41-43, tab. 4, col. 3 (datum 27th May, 1968), lectotypus (Kučera 2010, p. 834).

Characteristic species combination:

A) differential species $(\phi(\times 100) \geq 25)$ :

$\mathrm{E}_{3}$ : Abies alba (76), Betula carpatica (54), Acer pseudoplatanus (41), Populus tremula (41), Pinus sylvestris (41), Sorbus aucuparia (34),

$\mathrm{E}_{2}$ : Betula carpatica (62), Populus tremula (41), Pinus mugo (36), Abies alba (35), Lonicera nigra (28),

$\mathrm{E}_{1}$ : Betula carpatica (38), Salix silesiaca (25),

Empetrum nigrum agg. (81), Listera cordata (75), Vaccinium gaultherioides (73), Athyrium distentifolium (53), Polystichum lonchitis (35),

$\mathrm{E}_{0}$ : Rhytidiadelphus loreus (58),

B) constant species (constancy $>2 / 5$ ):

$\mathrm{E}_{3}$ : Picea abies (5/5), Sorbus aucuparia (5/5), Betula carpatica (5/5), Pinus cembra (5/5), Abies alba (4/5),

$\mathrm{E}_{2}$ : Pinus mugo (5/5), Picea abies (5/5), Betula carpatica (5/5), Sorbus aucuparia (4/5), Pinus cembra (3/5), Salix silesiaca (3/5),

E. Sorbus aucuparia (5/5), Pinus cembra (3/5), Betula carpatica (3/5),

Vaccinium vitis-idaea (5/5), Calamagrostis villosa (5/5), Vaccinium myrtillus (5/5), Homogyne alpina (4/5), Empetrum nigrum agg. (4/5), Listera cordata (4/5), Vaccinium gaultherioides (3/5), Athyrium distentifolium (3/5), Dryopteris dilatata (3/5), Lycopodium annotinum (3/5). 
This association was published already by Myczkovski and Lesiński (1974) from the northern part of granite High Tatras. Floristical composition is ruled by special habitat conditions as species Empetrum nigrum agg., Listera cordata, Vaccinium gaultherioides and Polystichum lonchitis grow in this community. High cover-abundance is constantly reached by Pinus mugo; uniqueness of this community among other non-carbonate associations is emphasized by presence of Betula carpatica. The constant presence of Abies alba in the published relevés is to be noted. These phytocoenoses require further study regarding the species composition of ground layer, as Myczkovski and Lesiński (1974) published only records of Rhytidiadelphus loreus within their relevés.

Detailed research of distribution of this Arolla pine woodland in the Tatras need to be performed because only five relevés have been published until now, along with the examination of the standard size of forest relevé plots, as Myczkovski and Lesiński (1974) used sizes 800-1 000-1 $200 \mathrm{~m}^{2}$.

Data: Myczkovski et Lesiński (1974): tab. 4, columns 2-6.

2. Calamagrostio variae-Pinion cembrae P. Kučera 2017, all. nova hoc loco

Original diagnosis: Seslerio tatrae-Pinetum cembrae P. Kučera 2017 ass. nova, Cystopterido montanae-Pinetum cembrae P. Kučera 2017 ass. nova

Nomenclatural type: Seslerio tatrae-Pinetum cembrae P. Kučera 2017 ass. nova, holotypus hoc loco.

Differential species $(\phi(\times 100) \geq 25)$ compared to Homogyno alpinae-Pinion cembrae:

$\mathrm{E}_{3}$ : Betula carpatica (67), Salix caprea (33),

$\mathrm{E}_{2}$ : Betula carpatica (49), Salix silesiaca (46), Lonicera nigra (38), Abies alba (28),

$\mathrm{E}_{1}$ : Daphne mezereum (65), Salix silesiaca (54), Ribes petraeum (50), Sorbus aucuparia (45), Betula carpatica (45), Pinus cembra (35), Abies alba (33), Acer pseudoplatanus (33), Lonicera nigra (31), Valeriana tripteris (89), Calamagrostis varia (81), Cystopteris montana (73), Cystopteris fragilis (73), Sesleria tatrae (73), Campanula tatrae ssp. tatrae (68), Soldanella hungarica (65), Clematis alpina (65), Asplenium viride (65), Hieracium murorum (63), Gymnocarpium dryopteris (62), Polygonatum verticillatum (60), Swertia perennis (57), Phyteuma spicatum (56), Moneses uniflora (51), Melampyrum sylvaticum (51), Pyrola rotundifolia (50), Cortusa matthioli (50), Bartsia alpina (50), Hedysarum hedysaroides (50), Galium schultesii (48), Luzula sylvatica (42), Cirsium erisithales (42), Carex sempervirens ssp. laxiflora (Schur.) Jáv. (42), Rhodiola rosea (42), Ranunculus alpestris (42), Androsace chamaejasme (42), Salix retusa (42), Bellidiastrum michelii (42), Poa alpina (42), Festuca versicolor (42), Moehringia muscosa (42), Salix reticulata (42), Crepis jacquinii ssp. jacquinii (42), Geranium sylvaticum (40), Leucanthemum rotundifolium (40), Huperzia selago (36), Adenostyles alliariae (36), Dryas octopetala (33), Pedicularis verticillata (33), Cerastium arvense ssp. glandulosum (33), Saxifraga paniculata (33), Crepis paludosa (33), Dactylorhiza majalis (33), Bistorta major (33), Erysimum witmannii (33), Helianthemum grandiflorum (33), Myosotis alpestris (33), Saxifraga wahlenbergii (33), Alchemilla sp. (33), Bistorta vivipara (33), Carex firma (33), Astragalus norvegicus (33), Phyteuma orbiculare (33), Acetosa arifolia (31), Selaginella selaginoides (31), Maianthemum bifolium (31), Mycelis muralis (31), Polystichum lonchitis (28), 
$\mathrm{E}_{0}$ : Mnium spinosum (48), Hylocomium splendens (39), Rhizomnium punctatum (36), Eurhynchium angustirete (33).

The alliance Calamagrostio variae-Pinion cembrae comprises carbonate Arolla pine forest phytocoenoses. Properties of calcium rich geological bedrock result in the origin of special soil conditions enabling occurrence of calciphytes and numerous list of nutrient demanding species. Species rich floristical composition is the reason for the delimitation of this group of communities into a separate alliance.

Phytocoenological relevés of Calamagrostio variae-Pinion cembrae were published only from the Belianske Tatry Mts (Slovakia); Barančok (2002) also refers to the unpublished data from Slovakian carbonate High Tatras. Carbonate Arolla pine forest stands were, in the past, distributed also in the West Tatras (Poland, Slovakia).

Based on floristical differences, further syntaxonomical study will clarify if carbonate woodlands with Arolla pine of other European countries belong to either Calamagrostio variae-Pinion cembrae or to its geographically vicariant alliance(s). Until now, only one carbonate Arolla pine association is mentioned in the national surveys: - Austria (Karner 2007): Pinetum cembrae Bojko 1931 [homotyp. syn. Rhododendro hirsuti-Pinetum cembrae (Bojko 1931) Karner et Willner in Willner et al. 2007]; - France (Bardat et al. 2011): Pinetum cembrae Bojko 1931.

\subsection{Seslerio tatrae-Pinetum cembrae P. Kučera, ass. nova hoc loco}

Original diagnosis: Kanka (2008a), p. 194-196, tab. 11, rel. 1-5. hoc loco.

Nomenclatural type: Kanka (2008a), p. 194-196, tab. 11, rel. 3, holotypus

Corresponding name: Cembro-Piceetum [ut Pino cembrae-Piceetum] calamagrostietosum variae Barančok 2002, nom. inval. (Art. 2b), Cembro-Piceetum [ut Pino cembrae-Piceetum] calamagrostietosum variae Barančok ex Kanka 2008, nom. inval. (Art. 3i, 5).

Characteristic species combination:

A) differential species $(\phi(\times 100) \geq 25)$ :

$\mathrm{E}_{3}$ : Salix caprea (59), Sorbus aucuparia (34),

$\mathrm{E}_{2}$ : Salix silesiaca (62), Lonicera nigra (52), Betula carpatica (43), Daphne mezereum (41), Pinus mugo (36), P. cembra (34), Sorbus aucuparia (34),

E1: Salix silesiaca (93), Daphne mezereum (89), Ribes petraeum (83),

Clematis alpina (89), Bartsia alpina (87), Cortusa matthioli (87), Pyrola rotundifolia (87), Hedysarum hedysaroides (87), Cystopteris fragilis (81), Sesleria tatrae (81), Swertia perennis (76), Salix retusa (74), Ranunculus alpestris (74), Cirsium erisithales (74), Carex sempervirens ssp. laxiflora (Schur) Jáv. (74), Androsace chamaejasme (74), Bellidiastrum michelii (74), Salix reticulata (74), Poa alpina (74), Rhodiola rosea (74), Moehringia muscosa (74), Festuca versicolor (74), 
Calamagrostis varia (74), Campanula tatrae ssp. tatrae (73), Phyteuma spicatum (71), Rumex alpestris (67), Geranium sylvaticum (67), Leucanthemum rotundifolium (67), Asplenium viride (67), Valeriana tripteris (65), Alchemilla sp. (59), Carex firma (59), Astragalus norvegicus (59), Pedicularis verticillata (59), Erysimum witmannii (59), Cerastium arvense ssp. glandulosum (59), Phyteuma orbiculare (59), Myosotis alpestris (59), Saxifraga wahlenbergii (59), Helianthemum grandiflorum (59), Saxifraga paniculata (59), Bistorta vivipara (59), B. major (59), Dryas octopetala (59), Selaginella selaginoides (51), Soldanella hungarica (50), Hieracium murorum (49), Crepis jacquinii ssp. jacquinii (44), Gymnocarpium dryopteris (43), Astrantia major (41), Pinguicula alpina (41), Poa chaixii (41), Tofieldia calyculata (41), Scabiosa lucida (41), Pleurospermum austriacum (41), Saxifraga aizoides (41), Cyanus mollis (41), Thalictrum aquilegiifolium (41), Ranunculus thora (41), Viola biflora (41), Geum rivale (41), Parnassia palustris (41), Melampyrum sylvaticum (39), Cystopteris montana (38), Polygonatum verticillatum (37), Luzula sylvatica (37), Moneses uniflora (35), Polystichum lonchitis (35), Huperzia selago (28),

$\mathrm{E}_{0}$ : Sphagnum capillifolium (55), Pleurozium schreberi (42), Marchantia polymorpha (41), Rhizomnium punctatum (36), Mnium spinosum (31),

B) constant species (constancy $>3 / 5$ ):

$\mathrm{E}_{3}$ : Pinus cembra (5/5), Sorbus aucuparia (5/5), Picea abies (4/5),

$\mathrm{E}_{2}$ : Picea abies (5/5), Pinus mugo (5/5), Salix silesiaca (5/5), Sorbus aucuparia (5/5), Betula carpatica (4/5), Pinus cembra (4/5),

$\mathrm{E}_{1}$ : Daphne mezereum (5/5), Ribes petraeum (5/5), Salix silesiaca (5/5), Sorbus aucuparia (4/5), Calamagrostis varia (5/5), Campanula tatrae ssp. tatrae (5/5), Clematis alpina (5/5), Cystopteris fragilis (5/5), Luzula sylvatica (5/5), Sesleria tatrae (5/5), Vaccinium vitis-idaea (5/5), Valeriana tripteris (5/5), Adenostyles alliariae (4/5), Asplenium viride (4/5), Bartsia alpina (4/5), Cortusa matthioli (4/5), Dryopteris dilatata (4/5), Gymnocarpium dryopteris (4/5), Hedysarum hedysaroides (4/5), Hieracium murorum (4/5), Huperzia selago (4/5), Phyteuma spicatum (4/5), Pyrola rotundifolia (4/5), Soldanella hungarica (4/5), Swertia perennis (4/5),

$\mathrm{E}_{0}$ : Dicranum scoparium (5/5), Hylocomium splendens (4/5), Pleurozium schreberi (4/5).

Association Seslerio tatrae-Pinetum cembrae represents species rich Arolla pine woodland on the carbonate bedrock (cf. Barančok 2002, Kanka 2008a). While Pinus mugo and Betula carpatica occur in the similar way as in CembroPiceetum Myczkowski et Lesiński 1974, this community differs strongly because of the presence of shrub species Daphne mezereum, Ribes petraeum and Lonicera nigra. The species composition of the field layer where Calamagrostis varia dominates is distinct (see the partial list above and Barančok (2002), Kanka (2008a)). The most common ground layer species are Dicranum scoparium, Hylocomium splendens, Pleurozium schreberi and Polytrichum formosum.

As of now, only five relevés of this distinct carbonate Arolla pine woodland have been published (Barančok et Kanka in Kanka 2008), all of them coming from the northeastern periphery of the Tatras (the Belianske Tatry Mts). According to Barančok (2002), similar phytocoenoses were also recorded in the northern carbonate zone of the High Tatras.

Data: Kanka (2008a): tab. 11 (5 relevés). 


\subsection{Cystopterido montanae-Pinetum cembrae P. Kučera, ass. nova hoco}

Original diagnosis: Kanka (2008a), p. 189-192, tab. 9, rel. 14-18.

Nomenclatural type: Kanka (2008a), p. 189, tab. 9, rel. 18, holotypus hoc loco.

Corresponding name: Vaccinio myrtilli-Piceetum pinetosum cembrae Kanka 2008, nom. inval. (Art. 5).

Characteristic species combination:

A) differential species $(\phi(\times 100) \geq 25)$ :

$\mathrm{E}_{3}$ : Betula carpatica (36),

$\mathrm{E}_{2}$ : Salix caprea (41), Abies alba (35),

$\mathrm{E}_{1}$ : Acer pseudoplatanus (59), Abies alba (59), Picea abies (45), Betula carpatica (38),

Cystopteris montana (59), Crepis paludosa (59), Dactylorhiza majalis (59), Maianthemum bifolium (58), Galium schultesii (56), Calamagrostis arudinacea (56), Mycelis muralis (51), Valeriana tripteris (46), Prenathes purpurea (42), Campanula serrata (41), Asplenium trichomanes ssp. quadrivalens (41), Epilobium montanum (41), Heracleum sphondylium (41), Cardaminopsis halleri (41), Listera ovata (41), Dentaria glandulosa (41), Polygonatum verticillatum (37), Calamagrostis varia (33), Soldanella hungarica (30), Hieracium murorum (29),

$\mathrm{E}_{\mathrm{B}}$ : Leucobryum glaucum (41), Mnium spinosum (31);

B) constant species (constancy $>3 / 5$ ):

$\mathrm{E}_{3}$ : Picea abies (5/5), Pinus cembra (5/5), Betula carpatica (4/5),

$\mathrm{E}_{2}$ : Sorbus aucuparia $(5 / 5)$,

$\mathrm{E}_{1}$ : Sorbus aucuparia (5/5), Picea abies (5/5), Pinus cembra (4/5),

Vaccinium myrtillus (5/5), Vaccinium vitis-idaea (5/5), Avenella flexuosa (5/5), Oxalis acetosella (4/5), Prenanthes purpurea (4/5), Luzula sylvatica (4/5), Homogyne alpina (4/5), L. luzuloides (4/5), Calamagrostis arundinacea (4/5), Valeriana tripteris (4/5), Cystopteris montana (4/5), Polygonatum verticillatum (4/5),

$\mathrm{E}_{0}$ : Hylocomium splendens (4/5).

Unlike in the previous association, Vaccinium myrtillus and V. vitis-idaea dominate the field layer of the community. Also, the total number of species is considerably lower. However, overall species combination with the presence of Prenanthes purpurea, Calamagrostis arundinacea, Valeriana tripteris, Cystopteris montana, Calamagrostis varia, Galium schultesii, Adenostyles alliariae and Soldanella hungarica enables differentiation of this Arolla pine woodland as a separate community within the carbonate types of Pinus cembra woodlands.

Betula carpatica could be the codominant tree species; Pinus mugo was not recorded. Lonicera nigra and Daphne mezereum could occur. Hylocomium splendens is the most frequent ground layer species, accompanied by Polytrichum formosum and Dicranum scoparium.

Relevés of Cystopterido montanae-Pinetum cembrae were published only by Kanka (2008a) from the Belianske Tatry Mts. This community is formed by extreme relief forms (steep slopes) which allow the existence of Pinus cembra 
population even below the usual vertical distribution of the species in the Tatras (see Kanka 2008a). Such special habitat force the development of the mentioned distinct species combination.

Data: Kanka (2008a): tab. 9, relevés 14-18.

\section{NOMENCLATURAL APPENDIX}

As mentioned above, a syntaxonomical unit for Arolla pine communities in the rank of an alliance was described already by Rivas-Martínez et al. (2011, p. 457: Pinion cembrae Rivas-Martínez in Rivas-Martínez et al. 2011). The authors cited within the alliance two names: Larici-Pinetum cembrae Ellenberg 1963 as the type of the alliance and Rhododendro-Vaccinietum cembretosum Pallmannn et Hafter 1933 Br.-Bl. in Br.-Bl et al. 1939 as the corresponding name for the former name. Before the cited alliance name could be nomenclaturally evaluated, names of the respective subordinated units (associations) have to be analysed.

(A.1) In the national vegetions surveys of Austria (Karner 2007) and Germany (Seibert 1992), the name Vaccinio-Cembretum (Pallmann et Hafter 1933) Oberdorfer 1962 [see ICPN Art. 14] was used, or eventually preferred before $L a$ rici-Cembretum Ellenberg 1963 [see ICPN Art. 14]; on the topic, see also Béguin and Theurillat (1982). Both of the names face serious nomenclatural issues.

At first sight, it might seem that Oberdorfer $(1962$, p. 37) described his Vaccinio-Cembretum (Pallmann et Hafter 1933) Oberdorfer 1962 as a nomen novum (cf. ICPN Art. 39). Leaving aside that Oberdorfer (1962) did not refer to the original diagnosis of the association (Art. 2b; Art. 39 does not provide exact rules for older nomina nova publications; however, compare Art. 2b: Note 3, Example 2), the part of phytosociolocal data of Pallmann and Hafter (1933) that should be assigned to Oberdorfer's (1962) name could be only "guessed" (cf. Art. 3n Example).

The more detailed syntaxa list of Oberdorfer et al. (1967, p. 53) provides more precise information: the author stated that "Vaccinio-Cembretum (Pallmann et Hafter 1933) Oberdorfer" was intended to be a raise of the subassociation Rhododendro-Vaccinietum cembretosum Pallmann et Hafter 1933 to the level of association. Therefore, only the name Vaccinio-Cembretum (Pallmann et Hafter 1933) Oberdorfer ex Oberdorfer et al. 1967 should be taken into account when referring to Oberdorfer's status novus of Vaccinio-Cembretum (i.e. Vaccinio-Cembretum (Pallmann et Hafter 1933) Oberdorfer 1962, nom. inval.).

Moreover, because Oberdorfer et al. (1967) once again did not accompany the name Vaccinio-Cembretum with reference to an original diagnosis (cf. Art. $2 \mathrm{~b}$ [Note 3, Example 2]), the validity of this name is questionable, too. Art. 27d specifies rules from the new rank changes (from the year 2002 onwards) and it is not clear whether an absence of a link (no reference to place of publica- 
tion in bibliography or elsewhere in the particular paper) to a corresponding name in the original rank is acceptable for older rank changes (Art. 27); this is a contradiction to ICPN Art. 2b: "The author citation as such is not sufficient". (Weber et al. 2000, p. 745). For the time being, it should be noted that VaccinioCembretum (Pallmann et Hafter 1933) Oberdorfer ex Oberdorfer et al. 1967 is actually a newer synonym of Larici-Cembretum Ellenberg 1963 (Oberdorfer et al. 1967, p. 53; the work does not include a list of bibliographic references).

(A.2) The publication of the name Larici-Cembretum Ellenberg 1963 is accompanied by special circumstances. The author (Ellenberg 1963, p. 295-297, 931) never fully adopted the proposed name Larici-Cembretum (Art. 3b) and at the same time never connected it properly with a reference to published specific original diagnosis, although he - elsewhere in the text - mentioned Pallmann and Hafter (1933) or other authors.

On page 296, Ellenberg published a table of three relevés of Pallmann and Hafter (1933) as a sample of "Lärchen-Arvenwälder und Alpenrosenheiden" [i.e. Rhododendro-Vaccinietum; the name Larici-Cembretum was not used!] and this here is considered as the crucial point of the nomenclatural evaluation of the name Larici-Cembretum Ellenberg 1963.

Examination of the relevés of Pallmann and Hafter (1933, Assoziationstabelle 1) demonstrate that the mentioned authors recorded in their relevés only presence of all tree layer species and their combined cover-abundance value in the respective relevé plots: the exact proof of such methodical approach is given in the table 19 (Pallmann and Hafter 1933, p. 400). Unfortunately, the use of such approach disqualifies the use of authors's data for later nomenclatural purposes and also, for the most part, for syntaxonomical utilization.

Moreover, based on this approach, it should be not accepted that Ellenberg (1963, p. 296, tab. 44) "constructed" cover-abundance values for Pinus cembra and Larix decidua for the three non-specified relevés of Pallmann and Hafter (1933) [i.e.: rel. 1 = Pallmann and Hafter 1933, Assoziationstab. 1, rel. 7; rel. 2 = Pallmann and Hafter 1933, Assoziationstab. 1, rel. 16; rel. 3 = Pallmann and Hafter 1933, Assoziationstab. 1, rel. 28; note P. Kučera]: data of Pallmann and Hafter (1933, p. 385-386) do not allow such construction, compare:

- rel. 8: “... 4 Arven",

- rel. 16: “... 1 Arve, 2 Lärchen".

Therefore I consider the name Larici-Cembretum Ellenberg 1963 as not usable for nomenclatural application (Art. 2b, Art. 7).

(A.3) As a solution to avoid all the above-mentioned nomenclatural issues, I propose here a conservation of a long-known and long-used name $L a$ rici-Pinetum cembrae Ellenberg et Klötzli 1972, which was accompanied with a direct reference to the original diagnosis (Art. 2b): 
Larici-Pinetum cembrae Ellenberg et Klötzli 1972, nomen conservandum propositum

Original diagnosis: Braun-Blanquet et al. (1954), tab. XVI, rel. 4-14.

Nomenclatural type: Braun-Blanquet et al. (1954), tab. XVI, rel. 4, lectotypus hoc loco.

(A.4) The name Larici-Pinetum cembrae Ellenberg et Klötzli 1972 should be conserved also against the older name Rhododendro-Cembretum Richard 1968, which, although mentioned by Ellenberg and Klötzli (1972, p. 739), did not come into wider use and remains unrecognised (ICPN Principle IV). Moreover, following the Art. 19a, a type of this name must be chosen from the subassociation typicum of Richard (1968), however, the available relevés have a canopy cover only 5-20\% (cf. Richard 1968, p. 15).

Rhododendro-Cembretum Richard 1968 (Art. 14)**

Original diagnosis: Richard (1968), tab. C, 19 relevés.

Nomenclatural type: Richard (1968), tab. C, rel. 4 (subassociation typicum), lectotypus hoc loco.

Rhododendro-Cembretum typicum Richard 1968 (Art. 14)

Original diagnosis: Richard (1968), tab. C, rel. 4-8.

Nomenclatural type: Richard (1968), tab. C, rel. 4, lectotypus hoc loco.

Rhododendro-Cembretum calamagrostietosum villosae Richard 1968 (Art. 14)

Original diagnosis: Richard (1968), tab. C, rel. 1-3.

Nomenclatural type: Richard (1968), tab. C, rel. 3, lectotypus hoc loco.

** In fact, Richard (1968, p. 15) used the name form "Rhododendro-Cembretum Bartoli $66 \mathrm{em}$. Richard". However, no reference to the work of Bartoli was made by Richard (1968); therefore, this author described a new association (Art. 2b: Note 3, Example 2). Although Bartoli (1966) used the name Rhododendro-Pinetum cembrae (cf. Table VIII, 705-706), this name was never consistently used by the author and remained not clearly adopted (Art. 3b; see Bartoli 1966, p. 638-667). Similarly as Rhododendro-Cembretum Richard 1968, the name Rhododendro-Pinetum cembrae Bartoli 1966 did not come into wider use.

(A.5) For the reasons mentioned above (see Larici-Cembretum Ellenberg 1963), the alliance name Pinion cembrae Rivas-Martínez in Rivas-Martínez et al. 2011 should be considered as an invalidly published name according to the Art. 2b, Art. 8.

(B.1) Finally, the name of a Romanian vegetation unit of the Pinus cembra woodland is to be reconsidered as well. Coldea et al. (2015) published a new name "Rhododendro myrtifolii-Pinetum cembrae (Borza 1934) Coldea nom. nov." with the reference to invalidly published name of Borza (1934) [i.e. Pinetum mughi piceetosum et cembretosum Borza 1934, nom. nud. (Art. 2b), nom. inval. (Art. 3e, Art. 6)] and with the reference to a chosen lectotype.

It is illegitimate to include Borza in the author citation of this association name, as the unit name should be described as a name of a new association, 
not as nomen novum. More important from the nomenclatural point of view is, however, the choice of lectotype made by Coldea et al. (2015, p. 223) from the relevés published by Coldea (1990, p. 157, tab. 70) within the association Rhododendro myrtifolii-Piceetum. Comparison of the Rhododendro myrtifolii-Pinetum cembrae lectotype with the type relevé (and also with the original diagnosis) of Rhododendro myrtifolii-Piceetum Coldea et Pînzaru 1986 (Coldea and Pînzaru 1986, p. 163) shows almost identical phytosociological content.

Because the type relevé of the association Rhododendro myrtifolii-Piceetum Coldea et Pînzaru 1986 was attached, accidentally, to the phytocoenosis determined by Picea abies, Pinus cembra and P. mugo (cf. Coldea et al. 2015, p. 223!), the name Rhododendro myrtifolii-Pinetum cembrae Coldea et al. 2015 became the younger syntaxonomical synonym of Rhododendro myrtifolii-Piceetum Coldea et Pînzaru 1986. Therefore, the relevant Arolla pine Romanian communities should be correctly named Rhododendro myrtifolii-Piceetum Coldea et Pînzaru 1986.

(B.2) The name Rhododendro myrtifolii-Pinetum cembrae was also published by Coldea (2014), however, albeit invalidly (Art. 3n, Art. 39b). The name Cembro-Piceetum Chifu et al. 1984 cited by Coldea et al. $(2015$, p. 223) is a younger homonym to Cembro-Piceetum Myczkowski et Lesiński 1974.

Acknowledgements - The author would like to thank to A. Asensi, R. Boeuf, M. Bartoli, J.-P. Theurillat and Th. Krämer for their valuable help with literature.

\section{REFERENCES}

Barančok, P. (2002): Limbovo-smrekové porasty východnej časti Tatier (Belianske Tatry a východná čast' Vysokých Tatier). - In: Kubíček, F., Kanka, R., Kollár, J. and Barančok, P. (eds): Ekológia a produktivita bylinnej vrstvy lesných ekosystémov: Zborník z medzinárodného odborného seminára, konaného v dňoch 13.-15. 11. 2001 na Výskumnej stanice [recte stanici] ÚKE SAV vo Východnej. Bratislava, pp. 120-129.

Barančok, P. and Varšavová, M. (1995): Spread and phytocoenological characteristic of ceder pine-spruce forests of Bielovodská dolina Valley in the Vysoké Tatry Mountains. Ekológia (Bratislava) 14(Suppl. 2): 35-51.

Bardat, J., Bioret, F., Botineau, M., Boullet, V., Delpech, R., Géhu, J.-M., Haury, J., Lacoste, A., Rameau, J.-C., Royer, J.-M., Roux, G. and Touffet, J. (2001): Extrait du prodrome des végétations de France. Version provisoire. - In: Bensettiti, F., Rameau, J.-C. and Chevallier, H. (coord.): «Cahiers d'habitats» Natura 2000. Connaissance et gestion des habitats et des espèces d'intérêt communautaire. 1 Habitats forestiers. MATE/MAP/ MNHN. La Documentation française, Paris, Vol. 2, pp. 397-400.

Bartoli, Ch. (1966): Études écologiques sur les associations forestières de la Haute Maurienne. - Ann. Sci. Forest. 123(3): 425-752. https://doi.org/10.1051/forest/19660301

Béguin, C. and Theurillat, J.-P. (1982): La forêt termophile d'arolles. - Candollea. 37: 349-379. 
Borza, A. (1934): Studii fitosociologice în Munţii Retezatului. - Bul. Grad. Bot. Muz. Bot. Cluj 14(1-2): 1-84.

Braun-Blanquet, J., Pallmann, H. and Bach, R. (1954): Pflanzensoziologische und bodenkundliche Untersuchungen im Schweizerischen Nationalpark und seinen Nachbarngebieten. II. Vegetation und Böden der Wald- und Zwergstrauchgesellschaften (Vaccinio-Piceetalia). - Ergebn. Wiss. Untersuch. Schweiz. Nationalparks IV: 200 pp., fig. tab. suppl.

Centrálna databáza fytocenologických zápisov. 2016 [disc]. Administrators K. Hegedüšová, J. Šibík. Bratislava: Botanický ústav SAV, Oddelenie geobotaniky, 1997- (cont. updated) http://ibot.sav.sk/cdf/index.html

Chytrý, M., Tichý, L., Holt, J. and Botta-Dukát, Z. (2002): Determination of diagnostic species with statistical fidelity measures. - J. Veg. Sci. 13(1): 79-90. https://doi. org/10.1111/j.1654-1103.2002.tb02025.x

Coldea, Gh. (1990): Munții Rodnei: Studiu geobotanic. - Edit. Acad. Române, Bucureşti, 184 pp.

Coldea, Gh. (2014): The class Vaccinio-Piceetea Br.-Bl. 1939 in the Romanian Carpathians. - Contr. Bot. 49: 129-132.

Coldea, Gh. and Pînzaru, Gh. (1986): La végétation de la reserve Bila-Lala des Monts Rodnei. - Contr. Bot. [1986]: 153-169.

Coldea, Gh., Indreica, A. and Oprea, A. (eds) (2015): Les associations végétales de Roumanie. 3. Les associations forestiéres et arbustives. - Presa Univ. Cluj., Accent, Cluj-Napoca, 286 pp.

Dostál, J. (1932): Rozšíření limby (Pinus Cembra) v Liptovských Holích. - Věda Přír. 13(4): 121-124.

Eggler, J. (1952): Übersicht der höheren Vegetationseinheiten der Ostalpen. - Mitt. Naturwiss. Vereines Steiermark 81-82: 28-41.

Ellenberg, H. (1963): Einführung in die Phytologie [von H. Walter]. Band IV. Teil 2. Vegetation Mitteleuropas mit den Alpen in kausaler, dynamischer und historischer Sicht. - Eugen Ulmer, Stuttgart, 948 pp.

Ellenberg, H. and Klötzli, F. (1972): Waldgesellschaften und Waldstandorte der Schweiz. Mitt. Schweiz. Anst. Forstl. Versuchswesen 48(4): 587-930.

Gams, H. (1936): Beiträge zur pflanzengeographischen Karte Österreichs. I. Die Vegetation des Großglocknergebietes. - Abh. zool.-bot. Ges. Wien 16(2): I-IV, 1-79. http://www. zobodat.at/publikation_series.php?id=6487

Guttová, A., Lackovičová, A. and Pišút, I. (2013): Revised and updated checklist of lichens of Slovakia (May 2013). - Biológia (Bratislava) 68(5): 845-850. https://doi.org/10.2478/ s11756-013-0218-y

Hennekens S. M. (2016): Turboveg for Windows [disc]. Ver 2.124. - S. M. Hennekens, Wageningen, http://www.synbiosys.alterra.nl/turboveg/

Hennekens, S. M. and Schaminée, J. H. J. (2001): Turboveg, a comprehensive database management system for vegetation data. - J. Veg. Sci. 12(4): 589-591. https://doi. org/10.2307/3237010

Horák, J. (1971): Westliche Tatra - Geobiozönosen der oberer Wald- und Krummholzgrenze. - Př́r. Práce Ústavu Českoslov. Akad. Věd v Brně 5(5): 1-47.

Jamnický, J. (1981): Rozšírenie a stav limby (Pinus cembra L.) v Západných Karpatoch. Zborn. Prác Tatransk. Nár. Parku 22: 5-29.

Jankovská, V. (1984): Late glacial finds of Pinus cembra L. in the Lubovnianská kotlina Basin. - Folia geobot. phytotax. 19(3): 323-325. 
Jankovská, V. (1988): A reconstruction of the Late-glacial and Early-Holocene evolution of forest vegetation in the Poprad Basin, Czechoslovakia. - Folia geobot. phytotax. 23(3): 303-319.

Kanka, R. (2008a): Lesy Belianskych Tatier. - Veda, Bratislava, 250 pp.

Kanka, R. (2008b): Limbové a limbovo-smrekové lesné spoločenstvá Belianskych Tatier. Phytopedon 7(1-2): 18-25.

Karner, P. (2007): Pinion mugo Pawt. 1928 s.l. - In: Willner, W. and Grabherr, G. (eds): Drescher, A. et al.: Die Wälder und Gebüsche Österreichs: Ein Bestimmungswerk mit Tabellen. 1 Textband. Elsevier, München, pp. 209-218.

Keller, W., Wohlgemuth, Th., Kuhn, N., Schütz, M. and Wildi, O. (1998): Waldgesellschaften der Schweiz auf floristischen Grundlage: Statistisch überarbeitete Fassung der «Waldgesellschaften und Waldstandorte der Schweiz» von Heinz Ellenberg und Frank Klötzli (1972). - Mitt. Eidgenoss. Forschungsans. Wald Schnee u. Landschaft. 73(2): 91-358. http://www.wsl.ch/dienstleistungen/publikationen/

Klika, J. (1948): Rostlinná sociologie (Fytocoenologie). - Melantrich, Praha. 384 pp.

Kobzáková, D. (1987): Fytocenologicko-ekologické pomery klimaxových smrečín pravých svahov Tichej doliny v Západných Tatrách. - MSc thesis, Prír fak., Univ. Komenského, Bratislava, 79 pp.

Krajina, V. (1933): Die Pflanzengesellschaften des Mlynica-Tales in den Vysoké Tatry (Hohe Tatra): Mit besonderer Berücksichtigung der ökologischen Verhältnisse. II. Teil. - Beih. Bot. Centralbl. 51, Abtlg. II(1): 1-224.

Kubíček, F., Šomšák, L., Šimonovič, V. and Szabo, J. (1992): Produkčno-ekologická a fytocenologická charakteristika bylinnej vrstvy lesných ekosystémov troch tatranských dolín (Furkotská, Siedmich prameňov, Zadné Medodoly). - Zborn. Prác Tatransk. Nár. Parku 32: 273-305.

Kubinská, A. (ed.) and Janovicová, K. (1998): Bryophytes. - In: Marhold, K. and Hindák, F. (eds): Checklist of non-vascular and vascular plants of Slovakia. Veda, Bratislava, pp. 297-331.

Kučera, P. (2010): Nomenclatural types of Picea abies syntaxa reported from Slovakia. - Biologia (Bratislava) 65(5): 832-836. https://doi.org/10.2478/s11756-010-0103-x

Kučera, P. (2012): Vegetačný stupeň smrečín v Západných Karpatoch - rozširenie a spoločenstvá : Spis so zvláštnym zretel’om na pohorie Vel'ká Fatra. - Botanická záhrada UK v Bratislave, pracovisko Blatnica, Blatnica, $342 \mathrm{pp}$.

Kukla, J., Kuklová, M. and Schieber, B. (2004): Responses of some herbs to different ecological conditions in spruce ecosystems of the Bielovodská dolina valley. - Ekológia (Bratislava) 23(3): 252-269.

Marhold, K., Goliašová, K., Hegedüšová, Z. et al. (1998): Ferns and Flowering Plants. - In: Marhold, K., Hindák, F. (eds) et al.: Checklist of non-vascular and vascular plants of Slovakia. Veda, Bratislava, pp. 333-687.

Matuszkiewicz, J. (1977): Przegląd fitosocjologiczny zbiorowisk leśnych Polski. Cz. 4. Bory świerkowe i jodłowe. - Phytocoenosis 6(3): 151-226, tab. suppl.

Matuszkiewicz, J. M. (2002): Zespoty leśne Polski. 1st ed. - Wydawnictwo Naukowe PWN, Warszawa, $360 \mathrm{pp}$.

Matuszkiewicz, W. (1982): Przewodnik do oznaczania zbiorowisk roślinnych Polski. - Państwowe Wydawnictwo Naukowe, Warszawa, 300 pp.

Matuszkiewicz, W. (2014): Przewodnik do oznaczania zbiorowisk roślinnych Polski. Wydawnictwo Naukowe PWN, Warszawa, 540 pp. 
Moravčíková, L'. (1987): Fytocenologicko-ekologická charakteristika lesných spoločestiev Krížnej doliny v Západných Tatrách. - MSc thesis, Prír fak., Univ. Komenského, Bratislava, 98 pp.

Myczkowski, S. (1969): Limba Pinus cembra L. - wysokogórskie drzewo lasu tatrzańskiego. - Zborn. Prác Tatransk. Nár. Parku 11: 99-138.

Myczkowski, S. and Lesiński, J. (1974): Rozsiedlenie rodzimych gatunków drzew tatrzańskich. - Stud. Ośrodka Dokum. Fizjograf. 3: 13-70.

Nad'ová, E. (1987): Fytocenologicko-ekologické pomery klimaxových smrečín l'avých svahov Tichej doliny (Západné Tatry). - MSc thesis, Prír fak., Univ. Komenského, Bratislava, 79 pp.

Oberdorfer, E. (1962): Systematische Übersicht der süddeutschen Vegetationseinheiten (Assoziationen und höhere Einheiten). - In: Oberdorfer, E. (ed.): Pflanzensoziologische Exkursionsflora für Süddeutschland und die angrenzenden Gebiete. Eugen Ulmer, Stuttgart, pp. 19-42.

Oberdorfer, E., Görs, S., Korneck, D., Lohmeyer, W., Müller, Th., Philippi, G. and Seibert, P. (1967): Systematische Übersicht der westdeutschen Phanerogamen- und Gefäßkryptogamen-Gesellschaften. Ein Diskussionentwurf. - Schriftenreihe Vegetationsk. 2: 7-62.

Pallmann, H. and Hafter, P. (1933): Pflanzensoziologische und bodenkundliche Untersuchungen im Oberengandin: mit besonderer Berücksichtigung der Zwergstrauchgesellschaften der Ordnung Rhodoreto-Vaccinietalia. - Ber. Schweiz. Bot. Ges. 42(2): 357-466. https://doi.org/10.5169/seals-28412

Pawłowski, B., Sokołowski, M. and Wallisch, K. (1928): Die Pflanzenassoziationen des Tatra-Gebirges. VII. Teil. Die Pflanzenassoziationen und die Flora des Morskie OkoTales. - Bull. Int. Acad. Polon. Sci., Cl. Math., Sér. B., Sci. Nat. Suppl. II: 205-272, tab., fig. mp. suppl.

Pišút, I. (ed.), Guttová, A., Lackovičová, A. and Lisická, E. (1998): Lichen-forming fungi (lichens). - In: Marhold, K. and Hindák, F. (eds): Checklist of non-vascular and vascular plants of Slovakia. Veda, Bratislava, pp. 229-295.

Podani, J. (2001a): SYNTAX 2000 [CD]. Multivariate data analysis package. - Budapest, http:// ramet.elte.hu/ podani/subindex.html

Podani, J. (2001b): SYN-TAX 2000 : Computer program for data analysis in ecology and systematics. User's manual. - Scientia Publishing, Budapest, $56 \mathrm{pp}$.

Rajcová, K. (1987): Fytocenologicko-ekologická charakteristika lesných spoločenstiev Kôprovej doliny vo Vysokých Tatrách. - MSc thesis, Prír fak., Univ. Komenského, Bratislava, 94 pp.

Richard, J.-L. (1968): Les groupements végétaux de la Réserve d'Aletsch (Valais, Suisse) avec un carte en couleurs. - Beitr. geobot. Landesaufn. Schweiz 51: 30 pp.

Rivas-Martínez, S., Asensi, A., Díez-Garretas, B. et al. (2011): Mapa de series, geoseries y geopermaseries de vegetación de España. II. - Itineraria Geobot. 18(2): 425-800.

Rodwell, J. S., Pigott, C. D., Ratcliffe, D. A., Malloch, A. J. C., Birks, H. J. B., Proctor, M. F., Shimwell, D. W., Huntley, J. P., Radford, E., Wigginton, M. J. and Wilkins, P. (eds) (1991): British plant communities. I. Woodlands and scrub. - Cambridge University Press, Cambridge, 398 pp.

Rübel, E. (1933): Versuch einer Übersicht über die Pflanzengesellschaften der Schweiz. - Ber. Geobot. Forschungsinstit. Rübel Zürich. 1932: 19-30. http://doi.org/10.5169/seals-377431

Samek, V., Jančařík, V., Kriesl, A. and Materna, J. (1957): Lesní společenstva severního úbočí Vysokých Tater (Část I. Javorová dolina). - Lesn. Čas. 3(1): 3-38.

Seibert, P. (1992): Klasse: Vaccinio-Piceetea Br.-Bl. in Br.-Bl. et al. 39. - In: Müller, Th., Oberdorfer, E. and Seibert, P. (eds): Süddeutsche Pflanzengesellschaften. Teil IV. Wälder und Gebüsche. A. Textband. Gustav Fischer, Jena, pp. 53-80. 
Šoltés, R. (1976): Phytozönotische Analyse des Verbandes Vaccinio-Piceion Br.-Bl. 1938 in den Westkarpaten. - Acta Fac. Rerum Nat. Univ. Comen., Bot. 24: 139-167.

Tichý, L. (2002): JUICE, software for vegetation classification. - J. Veg. Sci. 13(3): 451-453. https://doi.org/10.1111/j.1654-1103.2002.tb02069.x

Tichý, L. (2016): JUICE [disc]. Ver. 7.0.181. Program for analysis and classification of phytosociological tables and other quantitative ecological data sets. - Brno, http://www.sci.muni.cz/ botany/juice/

Tichý, L. and Chytrý, M. (2006): Statistical determination of diagnostic species for site groups of unequal size. - J. Veg. Sci. 17(6): 809-818. https://doi.org/10.1111/j.1654-1103.2006. tb02504.x

Valachovič, M. (2014): Limbové lesy v Mengusovskej doline (Vysoké Tatry). - Nat. Tutela 18(1): 21-28.

Vidličková, L'. (1989): Pino cembrae-Piceetum Myczkowski, Lesiński 1974 na území Krížnej doliny v Západných Tatrách. - Biológia (Bratislava) 44(1): 61-68.

Weber, H. E., Moravec, J. and Theurillat, J.-P. (2000): International Code of Phytosociological Nomenclature. 3rd ed. - J. Veg. Sci. 11(5): 739-768. https://doi.org/10.2307/3236580 